\title{
The Myth of 'Rebalancing' Retaliation in WTO Dispute Settlement Practice
}

\section{Citation}

Holger Spamann, The Myth of 'Rebalancing' Retaliation in WTO Dispute Settlement Practice, $9 \mathrm{~J}$. Int'l Econ. L. 31 (2006).

\section{Published Version}

http://jiel.oxfordjournals.org/content/9/1/31.full.pdf+html;doi: 10.1093/jiel/jgi054

\section{Permanent link}

http://nrs.harvard.edu/urn-3:HUL.InstRepos:12027772

\section{Terms of Use}

This article was downloaded from Harvard University's DASH repository, and is made available under the terms and conditions applicable to Other Posted Material, as set forth at http:// nrs.harvard.edu/urn-3:HUL.InstRepos:dash.current.terms-of-use\#LAA

\section{Share Your Story}

The Harvard community has made this article openly available.

Please share how this access benefits you. Submit a story.

Accessibility 


\title{
THE MYTH OF 'REBALANCING’ RETALIATION
}

\author{
IN WTO Dispute SetTlement PRActice
}

\author{
Holger Spamann*
}

\begin{abstract}
$\underline{\text { Abstract }}$
It is generally assumed that trade retaliation under the WTO performs some kind of 'rebalancing' by allowing the injured Member to suspend 'concessions and obligations' vis-à-vis the violating Member of a level equivalent to the level of 'nullification and impairment' suffered by the injured Member. This article argues that this perception is misguided. The article first questions if a sensible comparator exists with which equivalence for purposes of 'rebalancing' could be evaluated. It then argues that WTO arbitration decisions do not even succeed in their limited goal of providing for retaliation that will affect trade in the same amount as the WTO-inconsistent measure at issue. One reason is the use of an asymmetric and underspecified trade effects comparator. The other reason is very significant miscalculation of the trade effects of the violation, as shown by detailed legal-economic analysis of all relevant arbitration decisions. The decisions concerning countermeasures against prohibited export subsidies do not make any attempt at 'rebalancing' in the first place. The article considers political explanations of arbitration decisions. It concludes with some suggestions for improvement.
\end{abstract}

\footnotetext{
* John M. Olin Fellow, Harvard Law School; hspamann@law.harvard.edu. I wish to thank Lothar Ehring, Martin Gelter, Barak Orbach, Joel Trachtman, GangQiao Wang, and three anonymous referees for very helpful comments, and the John M. Olin Center for Law, Economics, and Business at Harvard Law School for financial support. All mistakes remain mine.
} 
INTRODUCTION

\section{THE TRADE EFFECTS COMPARATOR - CONCEPTUAL LIMITATIONS OF} 'REBALANCING' RETALIATION. .3

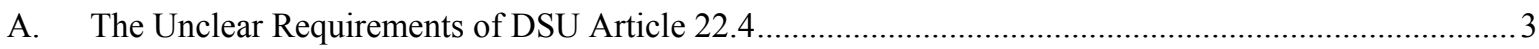

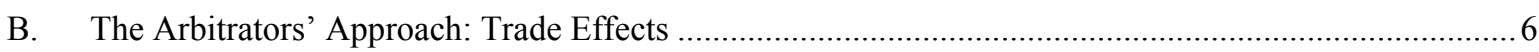

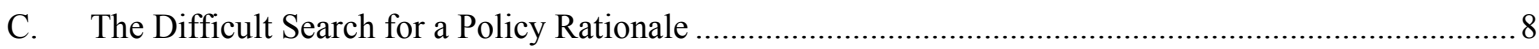

\section{OPERATIONALIZATION OF THE TRADE EFFECTS COMPARATOR........................................12}

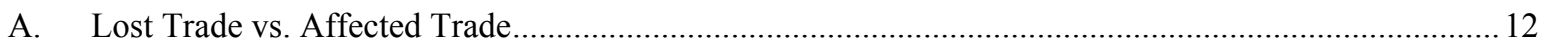

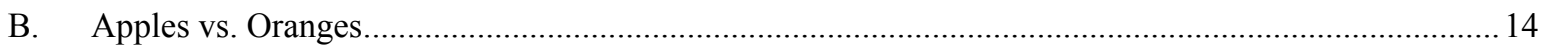

III. APPLICATION OF THE TRADE EFFECTS COMPARATOR - (MIS-

)CALCULATING THE LEVEL OF IMPAIRMENT.........................................................................................15

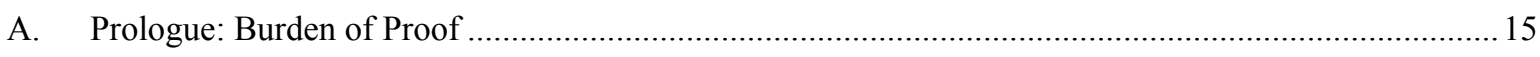

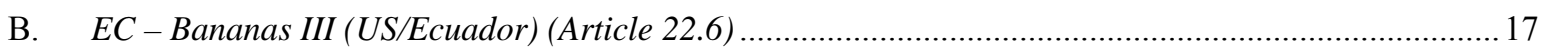

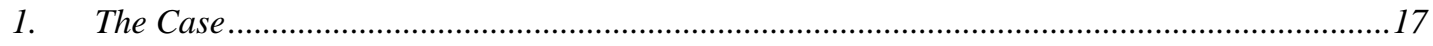

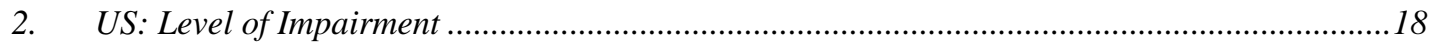

3. Ecuador: Level of Impairment........................................................................................

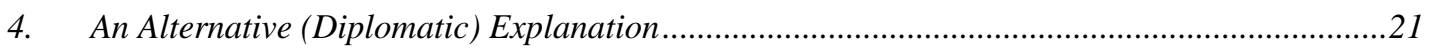

C. EC-Hormones (US/Canada) (Article 22.6) ……….......................................................................22

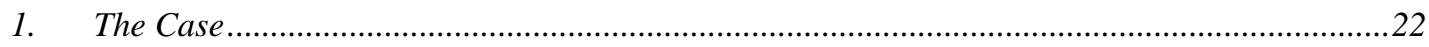

2. Level of Impairment: The Arbitrators' Approach.....................................................................22
a) Potential Trade.
b) Actual Trade

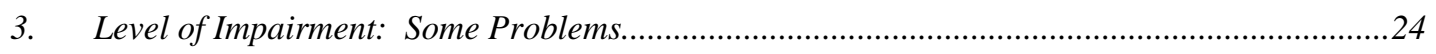

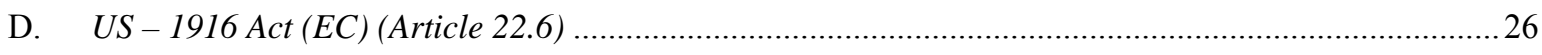

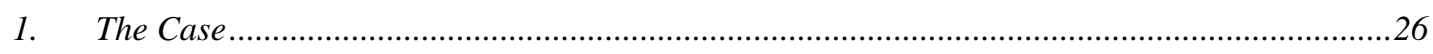

2. 'Mirror Legislation' and the Different Ways of Showing Equivalence .....................................27

3. An Alternative (Political Economy) Explanation ..........................................................................30

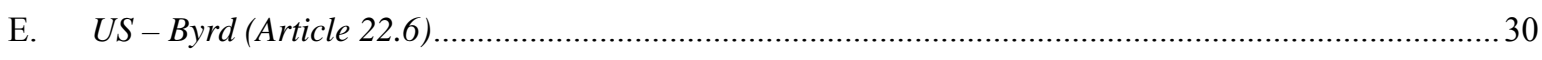

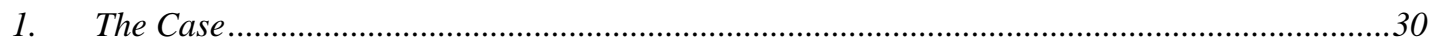


2. Level of Impairment: The Arbitrators’ Approach.........................................................................31

3. Level of Impairment: Some Elements of an Economic Analysis of CDSO ....................................34

F. $\quad$ Annex: US - Section 110(5) Copyright Act (Article 25.3) ............................................................... 36

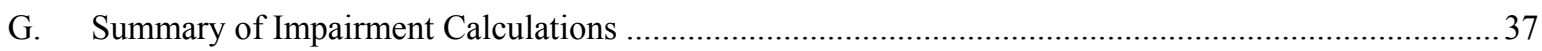

IV. THE SPECIAL CASE OF PROHIBITED SUBSIDIES AND APPROPRIATE

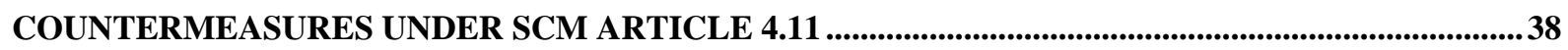

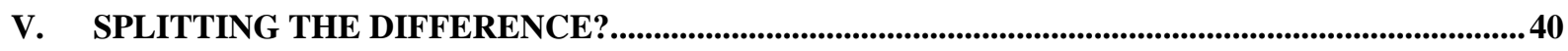

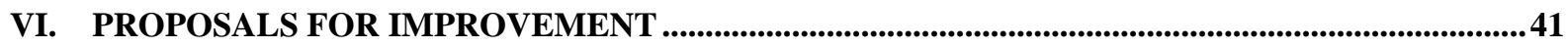




\section{INTRODUCTION}

The ability of the World Trade Organization ('WTO') to authorize trade retaliation as a response to persistent violations is perhaps the most salient, but also probably the most controversial feature of its dispute settlement system. Debate has been lively on the desirability of retaliation in general, and on its appropriate purpose, type, size, and implementing entity in particular. ${ }^{1}$ But most participants in the debate seem to take it for granted that the current system of trade retaliation performs some kind of 'rebalancing' by allowing the complaining Member to suspend 'concessions and obligations' under the WTO Agreements vis-à-vis the responding Member of a level equivalent to the level of 'nullification or impairment' caused by the latter's WTO-inconsistent measure (Article 22.4 of the Rules and Procedures Governing the Settlement of Disputes ('DSU')). ${ }^{2,3}$ This

\footnotetext{
${ }^{1}$ See Sections I.C and VI below for some elements of this debate.

${ }^{2}$ In this article, 'responding Member' refers to the defendant of the original Panel proceedings against which sanctions are being requested, while 'complaining Member' refers to the original plaintiff and applicant for sanctions authorization. 'Impairment', 'level of impairment', 'suspension' and 'level of suspension' will be used as shorthand for the official terminology 'nullification or impairment', 'level of nullification or impairment', 'suspension of obligations
} and other concessions' and 'level of suspension of obligations and other concessions', respectively.

${ }^{3}$ See Judith Hippler Bello, 'The WTO Dispute Settlement Understanding: Less Is More', 90 AJIL 416 (1996), at 417; Chad P. Bown, 'The Economics of Trade Disputes, the GATT's Article XXIII, and the WTO's Dispute Settlement Understanding', 14 Economics and Politics 283 (2002), at 283, 300; Chad P. Bown, 'On the Economic Success of the GATT/WTO Dispute Settlement', 86 The Review of Economics and Statistics 811 (2004), at 818; Robert E. Hudec, 'Broadening the Scope of Remedies in WTO Dispute Settlement', http://www.worldtradelaw.net/articles/hudecremedies.pdf (visited 19 December 2004) 21-23 (originally published in Friedl Weiss \& Jochem Wiers (eds), Improving WTO Dispute Settlement Procedures, (Cameron May 2000) 345 ); M. Rafiqul Islam, 'Recent EU Trade Sanctions on the US to Induce Compliance with the WTO Ruling in the Foreign Sales Corporations Case: Its Policy Contradictions Revisited', 38 JWT 471 (2004), at 474; Thomas Josling, 'WTO Dispute Settlement and the EU-US Mini Trade Wars: A Commentary on Fritz Breuss', 4 Journal of Industry, Competition and Trade 337 (2004), at 340-41; Thomas Juergensen, 'Crime and Punishment - Retaliation under the WTO Dispute Settlement System', 39 JWT 327 (2005), at n 7 ('rebalancing of trade benefits'); Wilhelm Kohler, 'The WTO Dispute Settlement Mechanism: Battlefield or Cooperation? A Commentary on Fritz Breuss', 4 Journal of Industry, Competition and Trade 317 (2004), at 331-32 ('rebalancing' of political economy benefits to participating governments); Robert Z. Lawrence, Crimes \& Punishments? - Retaliation Under the WTO, (Washington, DC: Institute for International Economics 2003; and http://bookstore.iie.com/merchant.mvc?Screen=PROD\&Product_Code=372 (visited 2 August 2005)) 26, 31, 39, 43-44; David Palmeter \& Stanimir A. Alexandrov, 'Inducing Compliance' in WTO Dispute Settlement', in Daniel L. M. Kennedy \& James D. Southwick (eds), The Political Economy of International Trade Law, (Cambridge: Cambridge University Press 2002) 647, at 647; Joost Pauwelyn, 'Enforcement and Countermeasures in the WTO: Rules are Rules - Towards a More Collective Approach', 94 AJIL 335 (2000), at 33941, 343-44. Also compare, less clearly, Kyle Bagwell \& Robert W. Staiger, The Economics of the World Trading System, (Cambridge, MA / London: MIT Press 2002) 97-9 with n 5, 104-05 with n 12; Jason Bernstein \& David Skully, 'Calculating Trade Damages in the Context of the World Trade Organization's Dispute Settlement Process', 25 Review of Agricultural Economics 385 (2003), at 392 ('reciprocity'); Jide Nzelibe, 'The Credibility Imperative: The Political Dynamics in the World Trade Organization's Dispute Resolution Mechanism', 6 (1) Theoretical Inquiries in Law (Online Edition) Article 7 (2005) (http://www.bepress.com/til/default/vol6/iss1/art7). But compare the somewhat skeptical opinions of Steve Charnovitz, 'Rethinking WTO Trade Sanctions', 95 AJIL 792 (2001), 822 ('re-equilibrate'; however, at 800-08 he also argues that in the transition from the General Agreement on Tariffs and Trade ('GATT') to the WTO the function of suspension has changed from 'rebalancing' to sanctions intended to force compliance) (accord Sungjoon Cho, 'The Nature of Remedies in International Trade Law', 65 University of Pittsburgh Law Review 763 (2003-04), at 770); Petros C. Mavroidis, 'Remedies in the WTO Legal System: Between a Rock and a Hard Place', 11 EJIL 763 (2000), at 808 ('some balance has been restored'). Brendan P. McGivern, 'Seeking Compliance with WTO Rulings: Theory, Practice and Alternatives', 38 Int'l L 141 (2002), at 144-45 argues that the goal of suspension has changed to inducing compliance in the WTO as opposed to the GATT, but he does not seem to argue that this has changed the operation of the GATT rebalancing approach. Ichiro Araki, 'Comment on Fritz Breuss: "WTO Dispute 
article argues that this perception is misguided. In current practice, WTO retaliation authorizations are, in reality, arbitrary. ${ }^{4}$

The article makes three mutually independent arguments to support this claim. The first, and weakest, argument corresponds to an ambitious understanding of 'rebalancing' as not just equalizing two given numbers, but doing so in a way that makes some sense from a policy perspective. Section I asks whether retaliation with equal 'trade effects', as endorsed by all decisions under Article 22.6 of the DSU ('Article 22.6 proceedings/decisions'), might in most cases be at best a very imprecise proxy for a meaningful measure of retaliation, while truly meaningful measures of 'rebalancing' retaliation will often not be achievable with the limited instruments (suspension, no forced monetary compensation) available under the WTO. This point has been explored before, of course. The original contribution of this article is to show that even if "trade effects' are accepted arguendo as a sensible paradigm, their flawed operationalization (Section II) and application (Section III) prohibit any serious reference to 'rebalancing' in this context. Section II shows that Article 22.6 decisions in effect use asymmetric definitions (measures) of 'trade effects' for impairment and suspension, respectively, and lump together incommensurate values in their calculations. Adding and comparing incommensurate numbers does not make sense, and equalizing two unequally defined numbers cannot be called 'rebalancing'. But in any event, even if one disagrees with this second argument, it seems impossible to escape the third argument set out in Section III: Article 22.6 decisions usually so significantly miscalculate the level of impairment as measured by 'trade effects' that the ultimate results must be called arbitrary even if the 'trade effects' paradigm and its operationalization are accepted. This is the main argument of the article, and it will be supported by discussing in considerable detail all decisions in standard Article 22.6 proceedings to date (EC - Bananas III, EC Hormones, US - 1916, US - Byrd; the arbitral award under Article 25 of the DSU ('Article 25 award') in US - Section 110(5) Copyright Act will be mentioned briefly). ${ }^{5}$

Settlement: An Economic Analysis of Four EU-US Mini Trade Wars"', 4 Journal of Industry, Competition and Trade 345 (2004), at 346-50, divides authors into those that believe that retaliation is designed to induce compliance and those that think it achieves 'rebalancing', referring (for the compliance inducement view) to, e.g., John H. Jackson, 'The WTO Dispute Settlement Understanding - Misunderstanding on the Nature of Legal Obligations', 91 AJIL 60 (1997). But see John H. Jackson, 'International Law Status of WTO Dispute Settlement Reports: Obligation to Comply or Option to "Buy Out"?', 98 AJIL 109 (2004), at 121-22 ('rebalancing' is a 'fallacy', notably because of the measurement problems discussed in the present article). Lastly, compare DSU Article 3.3: the prompt settlement of disputes is essential to maintain 'a proper balance between the rights and obligations of Members.'

${ }^{4}$ The article is concerned only with retaliation as authorized under DSU Article 22. It does not take any position on forms of 'rebalancing' that rely on additional commitments or compensation to 'rebalance' violations of or changes in original commitments, such as under DSU Article 22.1/2, GATT Article XXVIII, or Article XXI of the General Agreement on Trade in Services ('GATS').

${ }^{5}$ Decision by the Arbitrators, European Communities - Measures Concerning Meat and Meat Products (Hormones) Original Complaint by the United States - Recourse to Arbitration by the European Communities under Article 22.6 of the DSU (EC - Hormones (US) (Article 22.6)), WT/DS26/ARB, 12 July 1999; Decision by the Arbitrators, European Communities - Measures Concerning Meat and Meat Products (Hormones) - Original Complaint by Canada Recourse to Arbitration by the European Communities under Article 22.6 of the DSU (EC - Hormones (Canada) (Article 22.6)), WT/DS48/ARB, 12 July 1999; Decision by the Arbitrators, European Communities - Regime for the Importation, Sale and Distribution of Bananas - Recourse to Arbitration by the European Communities under Article 22.6 of the DSU (EC - Bananas III (US) (Article 22.6)), WT/DS27/ARB, 9 April 1999; Decision by the Arbitrators, European Communities - Regime for the Importation, Sale and Distribution of Bananas - Recourse to Arbitration by 
Section IV completes the picture with a brief report of the three Article 22.6 decisions concerning countermeasures against prohibited export subsidies in Brazil - Aircraft, US FSC, and Canada - Aircraft II. ${ }^{6}$ It is well known that these decisions did not even make an attempt at 'rebalancing'. In light of the foregoing, Section V floats the provocative hypothesis that what arbitrators have been doing in determining the permissible amount of suspension might simply be taking the average of both sides' positions. Section VI concludes with some very limited and tentative suggestions for improvement. It is acknowledged that this article's main contribution is destructive rather than constructive, but it is hoped that greater minds and institutions can find in this article useful elements to build on in further research and reforms.

\section{The Trade EfFects Comparator - Conceptual Limitations of}

\section{'REBALANCING’ RETALIATION}

As noted above, the possible conceptual limitations of 'rebalancing' retaliation, and in particular of the 'trade effects' comparator, are neither an original contribution nor the central arguments of this article. But before engaging in a discussion of the operationalization and application of the 'trade effects' paradigm of 'rebalancing' retaliation in the two following Sections, it is necessary to gain an understanding of what this paradigm means, and what it could or could not achieve, if correctly implemented.

\section{A. The Unclear Requirements of DSU Article 22.4}

Obviously, 'rebalancing' retaliation must mean more than countering a violation with some retaliatory measure regardless of type and size - otherwise the expression would be tautological, and the Article 22.6 procedure to determine the permissible size of the retaliatory measure would be pointless. ${ }^{7}$ Legally speaking, the answer to what

the European Communities under Article 22.6 of the DSU (EC - Bananas III (Ecuador) (Article 22.6)), WT/DS27/ARB/ECU, 24 March 2000; Decision by the Arbitrators, United States - Anti-Dumping Act of 1916 Original Complaint by the European Communities - Recourse to Arbitration by the United States under Article 22.6 of the DSU (US - 1916 Act (EC) (Article 22.6)), WT/DS136/ARB, 24 February 2004; Decision by the Arbitrators, United States - Continued Dumping and Subsidy Offset Act of 2000 - Original Complaint by the European Communities Recourse to Arbitration by the United States under Article 22.6 of the DSU (US - Byrd (EC) (Article 22.6)), WT/DS217/ARB/EEC, 31 August 2004 (following a joint procedure, identical or almost identical decisions were rendered on the parallel complaints of Brazil, Chile, India, Japan, Korea, and, in the parallel matter WT/DS234/ARB, Canada and Mexico (the 'requesting parties') - the text will cite to the named decision regarding the EC); Award of the Arbitrators, United States - Section 110(5) of the US Copyright Act - Recourse to Arbitration under Article 25 of the DSU (US - Section 110(5) Copyright Act (Article 25.3)), WT/DS160/ARB25/1, 9 November 2001.

${ }^{6}$ Decision by the Arbitrators, Brazil - Export Financing Programme for Aircraft - Recourse to Arbitration by Brazil under Article 22.6 of the DSU and Article 4.11 of the SCM Agreement (Brazil - Aircraft (Article 22.6)), WT/DS46/ARB, 28 August 2000; Decision by the Arbitrator, United States - Tax Treatment for 'Foreign Sales Corporations' - Recourse to Arbitration by the United States under Article 22.6 of the DSU and Article 4.11 of the SCM Agreement (US - FSC (Article 22.6)), WT/DS108/ARB, 30 August 2002; Decision by the Arbitrator, Canada Export Credits and Loan Guarantees for Regional Aircraft - Recourse to Arbitration by Canada under Article 22.6 of the DSU and Article 4.11 of the SCM Agreement (Canada - Aircraft Credits and Guarantees (Article 22.6)), WTO/DS222/ARB, 17 February 2003.

${ }^{7}$ Pointless, that is, with respect to its official formal goal, the determination of equivalence. It might still be useful to provide the appearance of equivalence, and to facilitate a political solution of the dispute, cf. Hudec, above n 3, at 2325 , and Sections IV and VI (particularly note 223 and accompanying text) below. 
'rebalancing' refers to is in one way very easy and in another very difficult. The easy answer is DSU Article 22.4, which provides:

The level of the suspension of concessions or other obligations authorized by the DSB shall be equivalent to the level of the nullification or impairment. (emphasis added)

Before conclusion of the WTO Agreements, the main standard for the permissible level of suspension was GATT Article XXIII.2, which used the looser criterion of 'appropriate' suspension. The GATT 1947 used the criterion of 'substantially equivalent' only to prescribe the permissible level of compensatory withdrawals/suspension in reaction to GATT-consistent tariff schedule modifications (Articles XVIII.7(b)/21, XXVIII.3/4(d)) or safeguards (Article XIX.3(a)) of another contracting party. While the criterion of 'appropriate' was often brought into proximity of 'substantially equivalent' by GATT players, the former was clearly significantly more open than the latter, and this distinction was affirmed by the Legal Advisor to the Director-General and the Deputy Director-General in GATT Council meetings as recently as in 1988, while the Uruguay Round negotiations were already in full swing. ${ }^{8}$ The DSU negotiators' choice of the equivalence standard in DSU Article 22.4 must therefore have been a conscious one, and EC - Bananas III (US) (Article 22.6) was right to insist on this choice as the relevant standard for the permissible level of suspension in WTO dispute settlement. ${ }^{9}$ Hence, in legal terms, 'rebalancing' in WTO dispute settlement refers to the equivalence of two levels, that of suspension on the one hand and that of impairment on the other: the complaining Member will be allowed to implement retaliation level with the violation's 'adverse impact' on it (cf. DSU Article 3.8).

The difficult part is, of course, to know what exactly 'equivalent' and 'level' refer to. Easy solutions do not exist. It is generally not sensible to ensure equivalence through identity of the retaliating measure with the violating one, because with asymmetric trade flows, even an identically specified measure will have different effects depending on the size and composition of the trade flow it applies to. ${ }^{10}$ And it is not possible to use revealed preferences to approximate equivalence through reversion to the status quo ante (i.e., to the mutual rights and obligations before conclusion of the trade agreement): violation of the agreement is usually only partial; concessions are made on an mostfavored-nation basis, while suspension affects only the relationship with the responding

${ }^{8}$ Cf. GATT, Analytical Index: Guide to GATT Law and Practice, vol $2\left(6^{\text {th }}\right.$ ed, Geneva / Bernan, MD: WTO and Bernan Press 1995) 696-99 (reporting discussion of the criterion of 'appropriate' by the various GATT actors).

${ }^{9}$ Cf. EC - Bananas III (US) (Article 22.6) para 6.1-6.5 (insisting on the standard in DSU Article 22.4 against suggestions of the US to use the looser standard of GATT Article XXIII).

${ }^{10}$ For example, a tariff on imports of bananas has very different meanings depending on whether a country is importing or exporting bananas; for an exception to this rule, cf. the discussion of US - 1916 Act (EC) (Article 22.6) below in Section III.D.2. In addition, suspension must be targeted against the responding Member, while the underlying violation will usually have covered trade with all Members, cf. DSU Article 22.2. This difference is not just formal. Trade flows at least of commodified goods can 'move around' a trade barrier that targets only one Member. For a documentation of a similar effect, see Chad P. Bown \& Meredith A. Crowley, 'Policy Externalities: How US Antidumping Affects Japanese Exports to the EU', European Journal of Political Economy (forthcoming 2006) and http://people.brandeis.edu/ cbown/research.html (visited 3 August 2005). 
Member $^{11}$; multilateral trade negotiations usually lead to multiparty tradeoffs that cannot be undone bilaterally; and the aggregation of obligations over multiple rounds of trade liberalization means that the status quo ante is an ill-defined concept anyway.

Hence, WTO practice must by necessity employ some kind of abstract comparator to measure the levels of suspension and of impairment, and to determine their equivalence. The central question is thus: which comparator(s)? ${ }^{12}$ For example, trade volume (in the sense of turnover), economic losses and gains (welfare effects), or (for tariffs) the amount of custom duties collected would appear to be at least plausible comparators.

Neither the text of DSU Article 22.4 nor its context resolve the issue of the legally correct comparator. ${ }^{13}$ Neither of the key terms is defined in the DSU or elsewhere. 'Impairment' relates to 'benefits' (cf. DSU Article 3.3), but these in turn are not defined themselves. ${ }^{14}$ And the objective and purpose (cf. Article 31(1) of the Vienna Convention $(\mathrm{VC})^{15}$ ) of ensuring 'equivalence' are at least ambiguous: The WTO's goals as announced in the preamble to the Marrakesh Agreement Establishing the WTO go far beyond a simple increase of trade volume as an end in itself, so that it is by no means obvious that the 'adverse impact' of a violation on the complaining Member (and hence permissible retaliation) should be determined only in terms of the volume of trade lost, irrespective of the economic meaning of this loss. ${ }^{16}$ It has of course often been said that the WTO protects 'conditions of competition', but this characterization just recasts the problem into how to measure changes in these 'conditions of competition'. Finally, the negotiation history (cf. VC Article 32) of DSU Article 22.4 during the Uruguay Round does not provide a solution either. 'Trade effects' were considered - but so was, e.g., 'damage suffered'. ${ }^{17}$

With respect to tariff changes only, an argument for the 'trade effects' approach is conceivable based on VC Article 31(4). It could be argued that for tariff changes, all original WTO Members 'intended' the term 'equivalent' to have the 'special meaning' of 'trade effects' that it may have had in pre-WTO practice. In 1988, the Legal Advisor to

\footnotetext{
${ }^{11}$ See Lawrence, above $n$ 3, at 28.

${ }^{12}$ Cf. Robert Howse \& Robert W. Staiger, 'United States - Anti-Dumping Act of 1916 (Original Complaint by the European Communities) - Recourse to arbitration by the United States under 22.6 of the DSU, WT/DS136/ARB, 24 February 2004', 4 World Trade Review 295 (2005), at 297 (noting that use of the term 'equivalent', rather than 'equal', argues for some flexibility in applying DSU Art. 22.4).

${ }^{13}$ See Juergensen, above $\mathrm{n} 3$.

${ }^{14}$ Although the words 'benefits of the complaining Member' are not in the text of DSU Article 22.4, it follows from the context, in particular Article 3.3 and GATT Article XXIII:1, that the provision must be read in this way.

15 Vienna Convention on the Law of Treaties, done at Vienna, 23 May 1969, http://www.un.org/law/ilc/texts/treaties.htm (visited 19 September 2005).

${ }^{16}$ See Kohler, above n 3, at 321 n 7, 332, 334, arguing for a general welfare approach; and for a broader view generally John H. Jackson, The World Trading System, (2 ${ }^{\text {nd }}$ ed, Cambridge, MA / London: MIT Press 1997) ch 1.2 and 1.3. Bernstein \& Skully, above n 3, at 386-387 explain that welfare is the standard in economic policy analysis, but endorse the trade effects approach based on a misunderstanding of the nature of relief available (they advocate trade effects as a measure of punitive damages) and a failure to appreciate the possibility of efficient breach (they think in terms of 'law enforcement').

${ }^{17}$ See Negotiating Group on Dispute Settlement, Special Distribution 21 September 1990, MTN.GNG/NG13/W/45.
} 
the Director General delivered a legal opinion to the GATT Council that for cases involving 'the withdrawal of tariff concessions, ... there were fairly well established criteria that were taken into account in the calculation of compensation', and he appeared to refer to 'trade effects'. ${ }^{18}$ If 'trade effects' had indeed been 'fairly well established' as the comparator to determine 'substantially equivalent' suspension/withdrawal of concessions under GATT Articles XIX.3(a) and XXVIII.3/4(d), it would be reasonable to infer that the DSU negotiators meant 'trade effects' when importing the equivalence criterion into DSU Article 22.4. There are, however, a number of limitations and caveats to this argument. Firstly, the Legal Advisor stressed that the criteria he outlined only applied to tariff renegotiations. ${ }^{19}$ Secondly, there appears to be no other documented evidence of the practice, as panels and working parties shied away from the analysis. ${ }^{20}$ Thirdly, other negotiation contexts primarily used the different approach of multiplying trade coverage by depth of tariff reduction to maintain reciprocity, which 'equivalent' withdrawals/suspension is supposed to sustain. ${ }^{21}$ Finally, the fact that the present argument has apparently never been invoked in Article 22.6 proceedings casts doubt on the existence of a common understanding among the original WTO Members. On the other hand, the last point could also be interpreted the other way: parties and arbitrators in particular in early Article 22.6 proceedings might not even have found it necessary to explain what seemed to them an obvious choice of 'trade effects'.

\section{B. The Arbitrators' Approach: Trade Effects}

However, the pioneering Article 22.6 decision EC - Bananas III (US) (Article 22.6) did purport to explain its choice of 'trade effects', and its argument was not based on preWTO practice. The arbitrators declared trade effects in the sense of lost trade (i.e., lost

\footnotetext{
${ }^{18} \mathrm{Cf}$. the statements of Mr. Lindén delivered at the GATT Council meeting of 4 May 1988, C/M/220, 35-36, http://gatt.stanford.edu (visited 19 September 2005). The 'fairly well established criteria' were described by Mr. Lindén as follows: 'The first criteria was the development of the imports during, normally, the last three years before the renegotiations started. What was taken into account was not just a statistical average, but also the trend in the development of trade during that period. Furthermore, account was taken of the size of the tariff increase being negotiated. Moreover, an estimate was made of the price elasticity of the products concerned.' The explanation ends here, but the reference to price elasticities points towards a 'trade effects' understanding.

${ }^{19}$ Ibid, at 36.

${ }^{20}$ The Panel Report, Canada - Withdrawal of Tariff Concessions, L/4636, adopted 17 May 1978, para 19 insisted that a calculation of 'substantially equivalent' withdrawals under GATT Article XXVIII.3(a) take into account the difference between old and new tariff rates, but '[i]n view of the complexity of assessing the value of a tariff binding, ... abstained from making any quantitative assessment in this respect.' The Working Party Report, Netherlands Action under Article XXIII:2, L/61, adopted 8 November 1952, charged 'to investigate the appropriateness of the [retaliatory] measure ..., having regard to its equivalence to the impairment suffered' (para 2), opined that 'a purely statistical test ... of the trade affected by the measures and countermeasures in question ... would not, by itself, be sufficient and that it would also be necessary to consider the broader economic elements entering into the assessment of the impairment suffered' (para 4) - but it did not provide any explanation of how it derived the numbers that it suggested to the Council for adoption (cf. para 6-7). Mr. Lindén, above n 18, at 35, said, '[t]here had never been any decision by the CONTRACTING PARTIES regarding the actual calculation of the level of damage.'

${ }^{21}$ See Anwarul Hoda, Tariff Negotiations and Renegotiations under the GATT and the WTO: Procedures and Practices, (Cambridge: Cambridge University Press 2001) 52-56; cf. Jackson, above n 16, at 147-48 (reporting use of both the 'trade coverage' and the 'trade effects' approach).
} 
trade flow, or turnover) the relevant comparator. ${ }^{22}$ More precisely, they meant trade directly between the complaining and responding Members. ${ }^{23}$ So, what mattered and what ultimately had to be set at equal amounts, according to the arbitrators, was the 'impact on the value of the relevant ... imports' ${ }^{24}$ The only argument provided for this choice was a non sequitur: In response to the parties' request to consider firms' costs and profits for calculating the level of impairment, they argued that the 'same basis' needed to be used for measuring the levels of suspension and impairment, and the basis for the former was 'the gross value of imports'. ${ }^{25}$ Obviously, this argument begs the question why the gross value of imports was necessarily the right basis for calculating the level of suspension. ${ }^{26}$

The other Article 22.6 decisions followed in fact or verbally and without further argument. $^{27}$ All decisions also agreed that suspension was supposed to induce compliance, but this was equally immaterial to all of them because none of them deduced any interpretative clues from this - in particular, they all agreed that even if higher retaliation would increase incentives for compliance, the permissible suspension was fixed at the level of equivalence, and 'punitive' suspension was not allowed. ${ }^{28}$ By

\footnotetext{
${ }^{22}$ Cf. EC - Bananas III (US) (Article 22.6) para 6.12, 7.1, 7.6.

${ }^{23}$ EC - Bananas III (US) (Article 22.6) para 6.12-6.18; accord EC - Hormones (US/Canada) (Article 22.6) para 41/42 n 35; US - Byrd (EC) (Article 22.6) para 3.128-3.129. Once trade effects were chosen as the relevant yard-stick, it followed naturally that indirect trade (i.e., exports to third-parties who use the goods/services to produce exports to the responding Member) had to be excluded. Otherwise, double-counting would be pervasive. The arbitrators also cited the rules of origin for goods.
}

${ }^{24}$ EC - Bananas III (US) (Article 22.6) para 7.1. Howse \& Staiger, above n 12, at 299-312, explore in more detail how these effects should be measured.

${ }^{25}$ EC - Bananas III (US) (Article 22.6) para 7.1 (against US argument) and 7.6 (against EC argument).

${ }^{26}$ In EC - Hormones (US/Canada) (Article 22.6) (para 13, also cf. EC - Bananas III (US) (Article 22.6) para 1.1, 7.1, 8.1 ), the complaining Members themselves suggested this approach (and prohibitive $100 \%$ tariffs on the targeted goods).

By contrast, in US - Byrd (Article 22.6), the arbitrators rejected the requesting parties' suggestion to measure suspension by the amount of retaliatory tariffs collected, and themselves suggested prohibitive $100 \%$ tariffs on imports presently valued at the level of impairment, see ibid, para 4.6, 4.9-4.12. The requesting parties' novel request in combination with their proposed methodology for calculating impairment may have represented an attempt to 'skim off' the illegal payments to US industry through tariffs. To make their case, the requesting parties invoked DSU Article 22.7 and argued, correctly, that no previous Article 22.6 decision had applied a trade effects test to determine the level of suspension, see ibid.

${ }^{27}$ Cf. EC - Hormones (US/Canada) (Article 22.6) para 38/37; US - 1916 Act (EC) (Article 22.6) para 5.23-5.25, 7.2; cf. Canada - Aircraft Credits and Guarantees (Article 22.6) para 3.21-3.22. The lack of reflection is betrayed by US 1916 Act (EC) (Article 22.6), the decision that insisted most strongly on the 'trade or economic [sic] effects' approach (see ibid, para 5.23, 7.2) while looking at effects very different from prior decisions ('economic' instead of 'trade' effects, in their parlance) and not explaining why either one or the other would be relevant in a given case: it can be gathered from their discussion that they primarily had in mind forced transfer payments such as customs duties, cf. ibid, para 5.30 (Howse \& Staiger, above n 12, at 299 n 6, also notice this inconsistency).

${ }^{28}$ See EC - Bananas III (US) (Article 22.6) para 6.3; US - 1916 Act (EC) (Article 22.6) para 5.4-5.8, 5.31, 6.2; cf. US - Section 110(5) Copyright Act (Article 25.3) para 4.27; but even US - FSC (Article 22.6) para 5.59-5.62 comes close to these statements. Also cf., e.g., Pauwelyn, above n 3, at 343; Chi Carmody, 'Remedies and Conformity under the WTO Agreement', 5 JIEL 307 (2002), at 309 (both arguing that retaliation is meant to induce compliance); contrast Palmeter \& Alexandrov, above n 3, at 650-52. Juergensen, above n 3, section II (p. 328), correctly points out that the objective of inducing compliance might be relevant for the interpretation of 'equivalence', but nowhere did the cited 
contrast, the Article 25 award in US - Section 110(5) Copyright Act evaluated impairment in terms of lost profits. ${ }^{29}$

\section{The Difficult Search for a Policy Rationale}

Unfortunately, an attempt to clarify the meaning of DSU Article 22.4 through a more thorough analysis of the object and purpose of 'equivalent' suspension leads straight into major problems, and even paradoxes, of current theory of the WTO Agreements. Three fundamental, and interacting, problems loom large in this analysis: First, and most obviously, the permissible level of retaliation should depend on the precise purpose of retaliation in the WTO (which is clearly more subtle than simply to enforce compliance at all cost, or else unlimited retaliation should be permitted $\left.{ }^{30}\right) .{ }^{31}$ But this in turn depends on the purpose of the WTO Agreements as a whole. And both could be analyzed under either a general welfare perspective or a political economy approach. ${ }^{32}$

The basic trade theory of Smith and Ricardo teaches that it is in each country's best interest to liberalize trade even unilaterally. ${ }^{33}$ Thus, no trade agreement and hence no trade retaliation to enforce it would be needed. This theory therefore gives no indication at all of the suitable level of retaliation (if anything, it would argue for abolishing retaliation altogether).

decisions do this, with the partial exception of US - Byrd (Article 22.6) para 4.25. On the fallacy of taking the induction of compliance as the only goal of the DSU's retaliation mechanism, see below $\mathrm{n} 30$.

The only Article 22.6 decision to adopt a more open approach was US - Byrd (Article 22.6), where arbitrators recognized the difference between trade effects properly speaking and broader economic effects, openly acknowledged that trade effect was not the only possible comparator (although they did not name any others), and argued that inducing compliance was at most one of a number of purposes of suspension. Nevertheless, they ultimately chose to look at trade effects for no better reason than that trade effects were certainly one permissible approach. See US - Byrd (EC) (Article 22.6) para 3.39-3.40, 3.70-3.74, 4.25, 6.2-6.4, but see Juergensen, above n 3, section III (at 329 et seq.) (sharply criticizing the arbitrators in this and other cases for adopting the trade effects approach without argument even though other approaches are possible and the wording of the relevant provisions inconclusive.). To their credit (and pushed by the EC), the US - Byrd (Article 22.6) arbitrators did engage in a proper argument why the level of impairment resulting from an illegal payment was not simply the amount of the payment itself. They argued that impairment was the result of the violation and thus had to be something different than the payment itself, ibid, para 3.16-3.56. But can we really say that a payment is the violation? And even if we distinguish violation and impairment conceptually, could not the amount of both be the same under certain conditions?

${ }^{29}$ See below Section III.F, text accompanying n 184-185.

${ }^{30}$ Cf. George W. Downs \& David M. Rocke, Optimal Imperfection - Domestic Uncertainty and Institutions in International Relations, (Princeton: Princeton University Press 1995) 82-84; Josling, above n 3, at 341 (the only criterion for retaliation designed to induce compliance is that it must at least wipe out the gain from the violation). In fact, if compliance at all cost were the only purpose of the DSU's rules for retaliation, it would not make any sense that DSU Article 22.4 require a comparison of the level of suspension with the level of impairment of benefits of the complaining Member - the complaining Member's woes as such have no influence on the responding Member's motivation to comply or continue the violation (see Downs \& Rocke, ibid, at 82).

${ }^{31}$ Some more general discussion of the purpose of retaliation in the WTO can be found below in Section VI.

${ }^{32}$ For an overview of the possible purposes of the WTO Agreements and analytical approaches, see Bagwell \& Staiger, above $\mathrm{n} 3$, ch 2.1 .

${ }^{33}$ Which is not to say that incidental effects cannot complicate the picture; cf., e.g., Paul A. Samuelson, 'Where Ricardo and Mill Rebut and Confirm Arguments of Mainstream Economists Supporting Globalization', 18(3) Journal of Economic Perspectives 135 (2004) (on effects resulting from technology transfer). 
To be sure, economists have long recognized terms-of-trade effects as a possible economically sensible (if egoistic) rationale for trade barriers. Each individual government with world market power can improve its country's terms-of-trade by imposing 'optimal tariffs' - but if all governments do so, the terms-of-trade effects offset each other and only an overall welfare loss ensues. ${ }^{34}$ So terms-of-trade effects would indeed provide (1) an economic argument for tariff-reducing trade agreements (rather than unilateral action) and (2) an economic justification for the arbitrators' trade effects approach: equal trade effects could ensure that the terms-of-trade effect of the violation be neutralized by retaliation. ${ }^{35}$ But terms-of-trade arguments as such - i.e., assuming governments are interested only in improving the general welfare of their respective country - apply only to classical tariffs and between big countries. Consequently, they fail to account for most measures relevant in actual WTO dispute settlement, like quotas, non-tariff measures, or (non-strategic) export subsidies (if anything, terms-of-trade considerations would make an economically rational country with market power impose an export tariff). ${ }^{36}$ Trade agreements and retaliation relating to the latter would appear to be motivated by mercantilist 'GATT-think' from the perspective of the aggregate welfare of individual nations. ${ }^{37}$

All of this might, however, make sense from a political economy perspective. ${ }^{38} \mathrm{~A}$ trade measure that is detrimental to the implementing country as a whole may still favor individual interests within that country, which in turn reward the domestic political actors who bestowed this favor upon them. Retaliation could aim to neutralize such rewards for the political actors of the responding Member, and hence to deter such protectionist strategies, by inflicting political harm of at least the same magnitude. ${ }^{39}$ However, such an aim could not explain why DSU Article 22.4 requires a comparison of the effect of suspension with the effect of the violation on the complaining Member ("nullification or impairment', 'adverse impact' [cf. DSU Article 3.8]). More generally, the deterrence aim alone could not explain any upper limit on retaliation. By contrast, the structure of the test required by DSU Article 22.4 would not stand in the way of Schwartz and Sykes' suggestion that retaliation is meant just to compensate the complaining Member's political actors for the political support lost because of the violation, while allowing for the possibility of 'efficient breach' if the responding Member's political actors find it

\footnotetext{
${ }^{34} \mathrm{Cf}$. Bagwell \& Staiger, above $\mathrm{n}$ 3, for a full exposition of the issues.

${ }^{35}$ See Lawrence, above n 3, at 43 .

${ }^{36}$ This also raises the issue if the comparator has to be uniform for all types of violations, or if trade effects could be used for WTO-inconsistent tariffs and one or more other comparators for other types of violations.

${ }^{37}$ Cf. Paul Krugman, 'What Should Trade Negotiators Negotiate About?', 35 Journal of Economic Literature 113 (1997).

${ }^{38}$ Cf. the "politically augmented terms-of-trade theory" of Bagwell \& Staiger, above n 3.

${ }^{39}$ See, e.g., Nzelibe, above n 3, and Judith Goldstein, 'International Institutions and Domestic Politics: GATT, WTO, and the Liberalization of Trade', in Anne O. Krueger (ed), The WTO as an International Organization (Chicago: University of Chicago Press 1998), 133. The concept includes the possibility that the political actors of the (potential) responding Member may ex ante deliberately agree to harsh punishment ex post in order to commit themselves not to give in to interest-group pressures calling for protection.
} 
favorable to maintain the violation in spite of the retaliation. ${ }^{40}$ In this view, trade effects provide a proxy for political rewards (which obviously cannot be measured directly). ${ }^{41}$ But whatever one may think of the political, moral or legal ${ }^{42}$ appeal of the theory in general, it 'explains' the trade effects comparator more by assertion than by argument: trade effects are such an imperfect proxy for political rewards that they cannot do much more than provide some rough order of magnitude for appropriate, but not truly 'equivalent', suspension. ${ }^{43}$ In fact, this view would bring DSU Article 22.4 closer to GATT Article XXIII and the US suggestion in EC - Bananas III (US) (Article 22.6) that precision in measuring damages is not required..$^{44}$

Nevertheless, it is perhaps the best one can do. By contrast, the use of a (national) economic gains/losses comparator might be appealing in the abstract, but its ultimate goal of allowing suspension that would fully compensate the complaining Member with economic gains of an equivalent amount as the losses it sustained from the violation will often not be achievable in practice. ${ }^{45}$ But for this problem, the economic gains/losses comparator would indeed make good sense even from a national welfare perspective. ${ }^{46}$ If suspension can provide the complaining Member with economic gains off-setting its economic losses from the violation, the complaining Member is fully compensated ex post, and sufficiently incentivized ex ante to implement retaliation when due, increasing

\footnotetext{
${ }^{40}$ See Alan O. Sykes, 'The Remedy for Breach of Obligations Under the WTO Dispute Settlement Understanding: Damages or Specific Performance?', in Marco Bronckers \& Reinhard Quick (eds), New Directions in International Economic Law, (The Hague, London, Boston: Kluwer Law International 2000) 347; and Warren F. Schwartz \& Alan O. Sykes, 'The Economic Structure of Renegotiation and Dispute Resolution in the World Trade Organization', $31 \mathrm{~J}$ Legal Studies S179 (2002); also cf. Lawrence, above n 3, at 43-44, and Kohler, above n 3, at 321-22 (trade effects as proxy for political economy effects).

${ }^{41}$ See ibid.

42 Jackson has argued forcefully that the DSU favors compliance and does not contemplate efficient breach as a permissible solution, see Jackson, above n 3; also see Howse \& Staiger, above n 12, at 313-15.

43 And this is indeed how Schwartz \& Sykes themselves view the matter: in their view, the main feature of the WTO dispute settlement system is to provide some observable limit on retaliation where the harm done (and thus 'obvious' limits to retaliation) is very difficult to observe, ibid, at 203.

${ }^{44} \mathrm{Cf}$. the US argument in EC - Bananas III (US) (Article 22.6) para 6.1.

45 In this connection, it is worth pointing out that while suspension will certainly create a welfare loss for the responding Member that is very important for purposes of deterrence, comparing this loss with, and setting it equal to, the welfare loss of the complaining Member from the violation would not seem to serve any sensible purpose, except under a rather archaic conception of justice ('an eye for an eye'). If compliance and deterrence is the goal, why should suspension's negative effect on the responding Member be limited by the violation's negative effect on the complaining Member? It is true that making the responding Member suffer the same loss as the complaining Member will ensure that the responding Member maintains the violation only if the violation as such yields a net welfare benefit (because the gain to the responding Member exceeds the loss of the complaining Member) - but this calculation omits the cost of retaliation (which doubles the losses, so that the violation may persist while the overall welfare balance is negative).

46 Another advantage of an economic gains/losses comparator is its generality as a comparator for international economic matters, as opposed to trade effects that fail in cases not involving blocked trade (As for example in US Section 110(5) Copyright Act, see below section III.F). Similarly, a level of impairment expressed in terms of economic losses would give a measure of appropriate monetary compensation payments, thus facilitating trade-friendly resolution of the conflict by mutual agreement
} 
the deterrence effect of retaliation. ${ }^{47}$ At the same time, the equivalence requirement of economic gains and losses would preserve the possibility of efficient breach by the responding Member where the aggregate costs (to all Members!) of compliance would outweigh those of a (compensated) breach. ${ }^{48}$ The problem is that the DSU's principal mechanism for retaliation, retaliatory tariffs, will often not be able to bestow equivalent economic gains on the complaining Member, for the reasons hinted at above. ${ }^{49}$

An economic gains/losses comparator for ensuring 'equivalence' might thus often lead to the conclusion that no retaliatory tariff can achieve an 'equivalent level' in the case at hand, prompting problematic recourse to cross-retaliation (particularly under TRIPS), or open capitulation of the WTO's dispute settlement system. The arbitrators in EC Bananas III (US/Ecuador) (Article 22.6) were probably aware of this problem ${ }^{50}$, and one can speculate that this might have been a reason for choosing the trade effects comparator. But whatever their motivation, it should be clear that the trade effects approach may hide, but cannot solve, the problems discussed above. In particular, it should always be kept in mind that behind equal gains and losses of trade flow can stand very different realities of respective welfare effects. ${ }^{51}$ In fact, since political constituencies presumably care about money in their pockets more than about their sales, economic gains/losses measured at the level of individual constituencies are probably a better proxy than trade effects for political economy effects - but the trade effects proxy has the 'advantage' of glossing over the asymmetric distributional effects of retaliation relied on by the political economy theory, and hence to hide that retaliation with equal trade effects will often provide a subsidy for one political constituency at the cost of the rest of the population, with a negative bottom line for the complaining Member as a whole.

\footnotetext{
${ }^{47}$ It should be added that the best possible result from retaliation under existing WTO law is prospective compensation for the ongoing violation. Distributive effects of retaliation are ignored here; it seems that such distributive effects could be sensibly addressed by the WTO only if the WTO could direct monetary compensation.

${ }^{48}$ See Howse \& Staiger, above $\mathrm{n}$, at 304-07 (however, they go on to discuss problems arising from spillover effects and resulting instability in a multilateral setting). On the question of the legality of efficient breach under the DSU, see above $\mathrm{n} 42$.

49 See, e.g., the following authors discussing the problems of developing countries in implementing retaliation: Charnovitz, above n 3, at 816-17; Gary N. Horlick, Problems with the Compliance Structure of WTO Dispute Resolution Process, in Kennedy \& Southwick, above n 3, 636, at 641-42; Mavroidis, above n 3, at 807-08, 811; Palmeter \& Alexandrov, above n 3, at 661-2; Pauwelyn, above n 3, at 338.

(Prospective) Compensation is possible mainly by means of an optimal tariff, an option available only to the biggest Members. Lawrence's statement, above $\mathrm{n} \mathrm{3}$, at 36-39, that compensation by retaliation could never be complete because of the efficiency loss involved would seem to go a bit too far - it would be true only if retaliation cannot go beyond, in tariff rates or product coverage, the original violation.

${ }^{50}$ Cf. the remarks in EC - Bananas III (Ecuador) (Article 22.6) para 95, 110, 126, and 177 on developing countries' problems.

${ }^{51}$ See, e.g., Kym Anderson, 'Peculiarities of Retaliation in WTO Dispute Settlement', 1 World Trade Review 123 (2002), at 127-29; Lawrence, above n 3, at 52-53; cf. the results of the general equilibrium calculations by Fritz Breuss, 'WTO Dispute Settlement: An Economic Analysis of Four EU-US Mini Trade Wars - A Survey', 4 Journal of Industry, Competition and Trade 275 (2004), at 287, 307; cf. Mavroidis, above n 3, at 805 (domestic value added matters).
} 
This review of the basic theory of retaliation in the WTO is by no means meant to be exhaustive. More sophisticated models exist, and some of them may support less than full compensation, including the 'trade effects' approach, as the best of many imperfect solutions. $^{52}$ The point to make here is that at present, it is not clear what 'rebalancing' should refer to as a matter of policy, nor what it does refer to as a matter of law. The one possible exception is with respect to tariff measures, for which retaliation with equal 'trade effects' is arguably both economically sensible (from a terms-of-trade perspective) and legally endorsed by DSU Article 22.4 (read in light of pre-WTO practice and VC Article 31(4)) - but of the Article 22.6 decisions to date, only EC - Bananas III (Ecuador (Article 22.6) dealt directly with a tariff measure.

\section{Operationalization OF THE TRADE EFFECTS COMPARATOR}

Be this as it may, this and the following Section will assume arguendo that the trade effects comparator provides a sensible measure of 'rebalancing' retaliation. The present Section is concerned with the operationalization of the trade effects comparator. What exactly do trade effects refer to? Article 22.6 decisions use asymmetric definitions of trade effects for impairment and suspension, respectively (A), and lump together incommensurate values in their calculations (B). The result is a travesty of equivalence and 'rebalancing'.

\section{A. Lost Trade vs. Affected Trade}

The introduction of the trade effects comparator in Section I.B referred to lost trade, or, in the words of EC - Bananas III (US) (Article 22.6), the 'impact on the value of the relevant ... imports' as the relevant definition of impairment. It was also reported that the arbitrators pretended to justify this choice of definition by the need to use the 'same basis' as for measuring suspension, which was the 'gross value of imports' to be targeted for retaliation. So the arbitrators' own argument for the use of trade effects implied the use of equal measures and definitions for impairment and suspension, respectively. Indeed, identical definitions and measures of the two sides to be equalized would appear to be the very core of the notions of equivalence and 'rebalancing', and none of the possible policy rationales for trade effects suggests otherwise. The arbitrators, however, asymmetrically defined impairment by lost trade, and suspension by affected trade. Upon closer reading, this in fact appears from the very terms chosen by the arbitrators when attempting to give the 'same basis' for impairment as for suspension: the 'impact on the value of the relevant ... imports' describes a trade measure's effect (lost trade), while the 'gross value of imports' to be targeted describes a trade measure's scope of application (affected trade). Quite obviously, lost trade will often be significantly less than affected

\footnotetext{
${ }^{52}$ See, e.g., Howse \& Staiger, above n 12, at 309-12 (retaliation calibrated by equal trade volume - however, they acknowledge that their model is based on the assumption of non-discriminatory violations and retaliations, while retaliation under DSU Article 22 is necessarily discriminatory, ibid, at 309 n 9); Downs \& Rocke, above n 30 , ch 4.
} 
trade. The result of the arbitrators' approach will thus be a systematic bias towards levels of suspension lower than levels of impairment by an order of magnitude. ${ }^{53}$

To make this point very clear, consider, e.g., a WTO-inconsistent $5 \%$ tariff on what used to be ten billion in annual trade, which results in an annual trade reduction of one billion, and 450 million in annual tariff revenue for the responding Member $(10 \mathrm{bn}=$ affected trade $\neq$ lost trade $=1$ bn). Under the arbitrators' approach, the complaining Member could not retaliate with a symetrical 5\% tariff on trade flows from the responding Member previously valued at ten billion per year. Instead, the maximum scope of application of a retaliatory tariff would be a trade flow of one billion per year, and the maximum available retaliation would thus be a prohibitive tariff obliterating this one billion of previous annual trade and yielding zero tariff revenue $(1 \mathrm{bn}=$ affected trade $=$ lost trade $=1 \mathrm{bn}$ ). This retaliatory measure would not offset the terms-of-trade effect of the WTO-inconsistent measure. Nor would it, presumably, offset the political losses of the complaining Member's political actors, who will have to deal not only with exporters suffering a one billion loss in annual turnover, but also with exporters having to pay 450 million in tariffs annually. It is hard to see how the levels of impairment and suspension could be called 'equivalent' in this example, or how this could be called 'rebalancing'. Not even a narrow focus on lost trade (which is equal for both measures) could justify this result: if lost trade were really all that mattered, then suspension too would have to be measured (limited) in terms of lost trade only (allowing the complaining Member to target a broader range of imports with a lower tariff rate). Another way to make the same point is to realize that the arbitrators' approach in fact imposes two cumulative restraints on the complaining Member's retaliatory measure: one regarding lost trade (which could be justified by the equivalence requirement if impairment is defined in terms of lost trade), and an additional one regarding affected trade (which has no basis in the DSU if lost trade is to be the relevant comparator under DSU Article 22.4).

Admittedly, the present discussion is moot for Article 22.6 proceedings involving a prohibitive measure, for which lost trade and affected trade coincide. But for the many non-prohibitive measures attacked under the WTO, lost trade is just the tip of the iceberg. Non-prohibitive measures include not only non-prohibitive tariffs, but also, e.g., those non-tariff barriers that can be circumvented by foreign producers by modifying all or some of their production. For example, in the EC-Hormones case, non-EC producers of beef were presumably able to shift at least some of their production to non-hormonetreated beef. Thus, beyond the trade lost as a result of the hormone-ban, the latter affected a much higher volume of trade (e.g., with the cost incurred in switching production, or with the cost of paying a non-prohibitive tariff).

\footnotetext{
${ }^{53}$ But see Lawrence, above $\mathrm{n}$ 3, at 52-53 (not taking this factor into account and fearing too high retaliation as a result of the complaining Member's freedom to choose particularly 'painful' sectors for retaliation).
} 


\section{B. Apples vs. Oranges}

The confusion of lost trade and affected trade is only the most important element of a broader pattern of adding and comparing incommensurate values. Arbitrators were often lead to compare apples and oranges in their calculations. ${ }^{54}$

The clearest example is the disrespect of the distinction between profits and turnover in EC - Bananas III. As will be discussed below, the measure of impairment added a value of profit (lost quota rents provided through import licenses) to a value of turnover (lost market shares in banana imports [Ecuador only] and distribution services). And while the measure of intellectual property rights suspension in the Ecuadorian case might formally comprise only turnover, this description glosses over a fundamental difference: while the value of EC imports displaced by products falsely carrying EC geographical indications is lost turnover that EC companies would have to earn with concomitant production expenses, the license value of EC copyrights and industrial designs used by Ecuador represents the loss of a pure rent in the short run perspective..$^{55}$

Another problem in EC - Bananas III was the aggregation and comparison of trade values for services and goods. These may describe very different economic realities. ${ }^{56}$ In the goods case, trade generally implies physical assets going from the territory of the exporting country to the territory of the importing country, and a corresponding transfer of money from the importing country to the exporting country. In the case of services, however, trade may mean nothing more than the turnover of an exporting country's service provider's affiliate inside the importing country. ${ }^{57}$ Thus, there may be no flow of funds and goods between the importing and exporting countries at all. This may have been the case, e.g., in EC - Bananas III (US) (Article 22.6), as American trading firms were at least partially operating through EC affiliates. ${ }^{58}$

In US - 1916 Act, the arbitrators counted as EC impairment (only) amounts payable by EC companies under judgments for, or settlements of, claims under the attacked US statute. ${ }^{59}$ Hence, impairment here referred to an amount of forced transfer payments, a quantity wholly incommensurate with suspension defined in terms of, e.g., the value of trade affected by a retaliatory tariff.

What emerges from these examples are the troubles of the trade effects comparator to deal with measures other than classical tariffs and perhaps quotas, for which it was originally developed (see above Section I.A). The trade effects comparator is at best

\footnotetext{
${ }^{54}$ Compare also the arbitrators' refusal in US - 1916 Act (EC) (Article 22.6) para 5.40-5.44 to consider at all the type of suspension applied by the $\mathrm{EC}$, and, consequently, the value that the number of allowed suspension would refer to.

${ }^{55}$ Cf. EC - Bananas III (Ecuador) (Article 22.6) para 160-163 (describing the measures used).

${ }^{56}$ This is related to the legal question of cross-sector retaliation, i.e., DSU Article 22.3. EC - Bananas III (US) (Article 22.6) para 3.1-3.10 granted the US the right to retaliate in the goods sector because the case involved a violation of goods rules, although the US was injured only in the services sector; but see O'Connor, above n 77, at 255.

${ }^{57}$ Cf. GATS Articles I.2(c), XXVIII(d)(i), so-called 'mode 3'.

${ }^{58}$ Cf. EC - Bananas III (US) (Article 22.6) para 5.62, 5.64.

${ }^{59}$ US - 1916 Act (EC) (Article 22.6) para 8.2.
} 
underspecified, and at worst incapable of providing a common denominator for the various effects relevant under WTO rules.

\section{Application of the Trade EfFects Comparator - (Mis-)Calculating the}

\section{LEVEL OF IMPAIRMENT}

The preceding two Sections attacked the concept and the operationalization of 'rebalancing' retaliation and the trade effects comparator. But the main argument of this article is yet to come. Even if retaliation with equal trade effects were theoretically a sensible and well operationalized concept, in practice Article 22.6 decisions usually so significantly miscalculate these trade effects that the ultimate results would still be arbitrary. To show this, Subsections B to F review in considerable detail the impairment calculations in all Article 22.6 decisions to date (EC - Bananas III, EC - Hormones, US 1916, and US - Byrd), and contrasts the Article 25 award in US - Section 110(5) Copyright Act. As a preliminary matter, Subsection A reviews the applicable rules on burden of proof..

\section{A. Prologue: Burden of Proof}

Burden of proof was clearly an important issue, given the difficulties in establishing counterfactuals and the complex economic issues involved. ${ }^{60}$ In theory, all Article 22.6 decisions were in perfect agreement, following the principles on burden of proof laid out by EC - Hormones (US/Canada) (Article 22.6): ${ }^{61}$ Generally, the burden of proof was

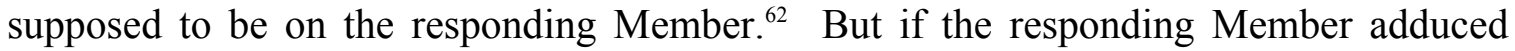
evidence and arguments sufficient to raise a prima facie case that the levels of impairment and suspension were not equivalent, the burden would then shift to the other party, who would fail unless it adduced sufficient evidence and arguments to rebut the presumption. If all arguments remained in equipoise, the party bearing the original burden of proof would lose. However, each party alleging a specific fact or claim had to prove its existence, and all parties were under a duty to produce evidence and collaborate

\footnotetext{
${ }^{60}$ These difficulties were explicitly acknowledged in most decisions, as discussed below, and by a WTO economist, Alexander Keck, 'WTO Dispute Settlement: What Role for Economic Analysis? A Commentary on Fritz Breuss', 4 Journal of Industry, Competition and Trade 365 (2004), at 366-67, 370; cf. Kohler, above n 3, at 334 (precise measurements impossible); Jackson (2004), above n 3, at 121-22 (quantification impossible). Breuss himself (above $n$ 51 , at $301,306-07)$ argues that the necessary calculations require a computable general equilibrium model, almost certain to be lacking in practice.

${ }^{61}$ The cryptic statements in US - Byrd (EC) (Article 22.6) para 2.25-27, while formally professing agreement with the prior decisions, seem to distribute the onus almost evenly, and this is implicit in the further statement in para 6.5 that a party should not be punished for a lack of data.

${ }^{62}$ Some statements in EC - Hormones (US/Canada) (Article 22.6) regarding the required level of proof took on a life of its own in subsequent decisions. The arbitrators cautioned 'against claims of lost opportunities where the causal link with the inconsistent [national rule] is less than apparent, i.e. where exports are allegedly foregone not because of the [inconsistent rule] but due to other circumstances.' (ibid, para 41/40) In the US case, they refused to take into account certain potential effects as 'too remote' and 'too speculative.' (EC - Hormones (US) (Article 22.6) para 77) These phrases were cited with approval in US - 1916 Act (EC) (Article 22.6) para 5.54-5.57, 5.69, 6.10, and US - Byrd (Article 22.6) para 3.76 and 3.129 in what sometimes seemed like a tension with the general rules on burden of proof.
} 
in presenting evidence to the arbitrators. ${ }^{63}$ As a peculiarity of Article 22.6 proceedings (that always required a number as a result, as opposed to a binary yes/no answer), the arbitrators thought that they would have to make their own estimate where neither party's assessment of the equivalent level of suspension was appropriate. ${ }^{64}$ Even though the full meaning of these statements on burden of proof will only become apparent in the discussion of their application in the actual decisions, some general comments can already be made.

The most fundamental issue here is the basic allocation of the burden of proof on the responding Member. The arbitrators based this on the general and accepted rule that a party claiming a violation of WTO rules must prove its claim. The decisive additional argument was the peculiar structure of Article 22.6 proceedings: while the complaining Member has to apply to the DSB for permission to suspend concessions, it is the responding Member who must initiate Article 22.6 proceedings claiming a violation of DSU Article 22.4 by the complaining Member's suspension request. ${ }^{65}$ But formalism aside, there can be little doubt that the complaining Member is the real claimant seeking a remedy (suspension), and it is after all the complaining Member who initiates the overall procedure by applying to the DSB for this remedy (DSU Article 22.2). In this position, the complaining Member would bear the burden of proving a particular amount of 'damages' in all (or almost all) other systems of adjudication (if only for the reason that the inverse rule would force a party [here: the respondent Member] to prove a negative ${ }^{66}$ ). Of course one could argue that Article 22.6 proceedings resemble not so much actions in damages as an enforcement action, in which different rules apply - but this argument would seem to abandon the notion of 'rebalancing' and Article 22.6's 'equivalence' requirement because enforcement measures are usually deliberately set independently of (and higher than) the level of discernible damages of the applicant.

As to the operation of burden of proof, it has been forcefully argued elsewhere that the peculiar formulation of a prima facie case causing a shift of the burden of proof may turn the burden of proof on its head. ${ }^{67}$ This is indeed what happened in US - 1916 Act (EC)

\footnotetext{
${ }^{63}$ EC - Hormones (US/Canada) (Article 22.6) para 9-11; EC - Bananas (Ecuador) (Article 22.6) para 37-38; US 1916 Act (EC) (Article 22.6) para 3.2-3.6; also see US - Section 110(5) Copyright Act (Article 25.3) para 4.4-4.5; Brazil - Aircraft (Article 22.6) para 2.8-2.9; US - FSC (Article 22.6) para 2.11; Canada - Aircraft Credits and Guarantees (Article 22.6) para 2.6-2.8; cf. for general WTO law the leading case WTO Appellate Body Report, United States Measure Affecting the Import of Woven Wool Shirts and Blouses from India (US - Shirts and Blouses), WT/DS33/AB/R, adopted 23 May 1997, at 14, 16-17.

${ }^{64}$ EC - Hormones (US/Canada) (Article 22.6) para 12, 42/41; EC - Bananas (Ecuador) (Article 22.6) para 18; US 1916 Act (EC) (Article 22.6) para 3.2-3.6, 4.6-4.9; US - Byrd (EC) (Article 22.6) para 3.69, 3.115, Annex B para 7; US - Section 110(5) Copyright Act (Article 25.3) para 4.5.

${ }^{65}$ See EC - Hormones (US/Canada) (Article 22.6) para 9; EC - Bananas (Ecuador) (Article 22.6); cf. Brazil - Aircraft (Article 22.6) para 2.8; US - FSC (Article 22.6) para 2.8, 2.10; Canada - Aircraft Credits and Guarantees (Article 22.6) para 2.6; cf. Appellate Body Report, US - Shirts and Blouses, above n 63, at 16.

${ }^{66}$ This is why seemingly marginal issues like the timing of the submission of a 'methodology paper' by the complaining Member can assume such high importance in DSU Article 22.6 proceedings; compare in particular EC Bananas (Ecuador) (Article 22.6) para 15-36, 39-41; also Canada - Aircraft Credits and Guarantees (Article 22.6) para 2.9-2.14.

${ }^{67}$ Joost Pauwelyn, 'Evidence, Proof and Persuasion in WTO Dispute Settlement - Who Bears the Burden?', 1 JIEL 227 (1998).
} 
(Article 22.6). ${ }^{68}$ Similarly, the arbitrators' approach to make their own estimate if neither party's assessment is appropriate risks abandoning the rules on burden of proof altogether if it means anything more than that a party bearing the burden of proof and claiming 100 but proving only 80 will get 80 instead of $0 .{ }^{69}$ For example, US - Byrd (Article 22.6)'s treatment of the pass-through rate seems to have fallen into this trap..$^{70}$

\section{B. EC - Bananas III (US/Ecuador) (Article 22.6)}

\section{The Case}

In a nutshell, EC - Bananas III looked like this at the time of the first (US) Article 22.6 proceeding: ${ }^{71}$ In line with its scheduled WTO commitments, the EC maintained a tariffquota of $€ 75$ per ton for 2.553 million tons of bananas per year, and an out-of-quota tariff of around $€ 700$ per ton for all imports above that limit. ${ }^{72}$ In addition, the EC admitted bananas grown in African, Caribbean and Pacific ('ACP') countries at zero tariff; this was WTO-legal under the so-called Lomé waiver expiring on 29 February 2000. ${ }^{73}$ However, the EC violated WTO non-discrimination provisions in apportioning and administering the tariff-quota. Firstly, in violation of GATT Article XIII, the EC did not apportion the third-country tariff-quota among various banana-growing countries (i.e., where do the imported bananas actually come from?) in proportion to import shares that

\footnotetext{
${ }^{68}$ See below Section III.D.2.

${ }^{69}$ Cf. David Palmeter \& Petros C. Mavroidis, Dispute Settlement in the World Trade Organization: Practice and Procedure, ( $2^{\text {nd }}$ ed, Cambridge: Cambridge University Press 2004) 272 ('the "duty to collaborate in presenting evidence" imposes what is, in all but name, a burden of proof on the Member being challenged').

${ }^{70}$ See below text accompanying n 161 to 163 .

${ }^{71}$ For a full overview of the entire EC - Bananas saga see, e.g., Norio Komuro, 'The EC Banana Regime and Judicial Control', 34 (5) JWT 1 (2000); Mauricio H. Salas \& John H. Jackson, 'Procedural Overview of the WTO EC-Banana Dispute', 3 JIEL 145 (2000); and John H. Jackson \& Patricio Grane, 'The Saga Continues: An Update of the Banana Dispute and Its Procedural Offspring', 4 JIEL 581 (2001); and, focused on the WTO disputes, Raj Bhala, 'The Bananas War', 31 McGeorge Law Review 839 (2000).

${ }^{72}$ See EC - Bananas III (US) (Article 22.6) para 5.4; WTO Panel Report, European Communities - Regime for the Importation, Sale and Distribution of Bananas (EC - Bananas III), WT/DS27/R/USA, WT/DS27/R/MEX, WT/DS27/R/GTM, WT/DS27/R/HND, adopted 25 September 1997, para III.7, III.32, 7.64; WTO Panel Report, European Communities - Regime for the Importation, Sale and Distribution of Bananas - Recourse to Article 21.5 by Ecuador (EC - Bananas III (Ecuador) (Article 21.5)), WT/DS27/RW/ECU, adopted 6 May 1999, para 2.4. Technically, the EC tariff quota bound in the EC schedules is only 2.2 million tons. But the EC autonomously increased this by 353,000 tons following the accession of Austria, Finland, and Sweden, as the EC was arguably required to do under GATT XXIV.5(b) and the terms of the schedule.

${ }^{73}$ See EC - Bananas III (US) (Article 22.6) para 7.7 and, less clearly, WTO Appellate Body Report, European Communities - Regime for the Importation, Sale and Distribution of Bananas (EC - Bananas III), WT/DS27/AB/R, adopted 25 September 1997, para 188. Formally, in the eyes of the arbitrators and the Appellate Body, the EC regime violated WTO rules because the Lomé waiver only covered unlimited access (i.e., a so-called tariff preference) as opposed to a preferential tariff-quota for ACP bananas as maintained by the EC, EC - Bananas III (US) (Article 22.6) para 5.3-5.19; Appellate Body Report, EC - Bananas III para 179-188; Panel Report, EC - Bananas III (Ecuador) (Article 21.5) para 6.18-6.29. This was inconsequential though since the ACP tariff-quota of 857,000 tons was never fully filled anyway, cf. EC - Bananas III (US) (Article 22.6) para 7.7. There was thus nothing to 'choose' in setting the right counterfactual, as the arbitrators described their task (see ibid) - if a certain violation of legal rules is inconsequential, then that is it.
} 
would obtain in the absence of a quota. The EC favored certain countries at the expense notably of Ecuador. ${ }^{74}$ Secondly, the EC violated GATS Articles II (most-favored-nation treatment) and XVII (national treatment) by granting import licenses for filling the quotas (i.e., who is allowed to bring in those bananas?) in a discriminatory way, to the detriment notably of US trading firms such as Chiquita and Dole, and the Ecuadorian firm Noboa. ${ }^{75}$

\section{US: Level of Impairment}

This should have been the starting point of the arbitrators' main analysis in the Article 22.6 proceeding, i.e., assuring equivalence of the levels of impairment and suspension. In the convoluted bananas proceeding, however, it took the arbitrators about 40 pages to get there in the US case - and it was the end point. The only statement that followed in ECBananas III (US) (Article 22.6) was the following:

[Our] task is reduced to working out the differences between the two scenarios [WTO-consistent vs. WTO-inconsistent allocation of import licenses] in (a) the US share of wholesale trade services in bananas sold in the European Communities and (b) the US share of allocated banana import licenses from which quota rents accrue. Using the various data provided on US market shares, and our knowledge of the current quota allocation and what we estimate it would be under the WTOconsistent counterfactual chosen by us, we determine that the level of nullification and impairment is US\$191.4 million per year. ${ }^{76}$

Besides the lack of explanation of how that figure was derived, notice also that there was no mention of the parties' positions and burden of proof, which is all the more surprising given that the bottom line given by the arbitrators was less than $60 \%$ of the lowest figure calculated by the US - and the EC was supposed to bear the burden of proof. ${ }^{77}$ To the arbitrators' credit, it should be mentioned that the WTO secretariat and/or the parties may have asked the arbitrators not to disclose their calculations. ${ }^{78}$ However, while this may excuse the formal shortcoming of not reporting the calculations, it only exacerbates the strong doubts that persist as to the substantive accuracy of the arbitrators' result.

As to item (a), the US share of wholesale trade services in bananas sold in the EC, it is key to know that the banana import licenses were transferable. ${ }^{79}$ Hence, whatever the initial allocation of licenses, we would have expected them to be purchased by those who could use them most profitably (because they could pay the initial holder whatever that

\footnotetext{
${ }^{74}$ See Panel Report, EC - Bananas III (Ecuador) (Article 21.5) para 6.33-50; EC - Bananas III (US) (Article 22.6) para 5.20-5.33.

${ }^{75}$ Cf. EC - Bananas III (US) (Article 22.6) para 5.34-5.95; Panel Report, EC - Bananas III (Ecuador) (Article 21.5) para 6.81-6.134, 6.143-6.149.

${ }^{76}$ EC - Bananas III (US) (Article 22.6) para 7.8.

${ }^{77}$ Cf. EC - Bananas III (US) (Article 22.6) para 7.5. It is true that the US calculations were based on different counterfactuals, but these different counterfactuals had been suggested by the arbitrators, ibid para 7.4. The lack of explanation is also noticed by Hudec, above n 3, at 24-25; McGivern, above n 3, at 151; Breuss, above n 51, at 292-93; and Bernard O'Connor, 'Remedies in the World Trade Organization Dispute Settlement System - The Bananas and Hormones Cases', 38 JWT 245 (2004), at 254-55.

${ }^{78}$ See O'Connor, ibid, at 254 n 49.

${ }^{79}$ Cf. EC - Bananas III (US) (Article 22.6) para 5.62, 5.67 with n 44 (discussing data of how many licenses were sold).
} 
initial holder would have earned plus a little extra, and still make a profit - so-called Coasean reallocation). The arbitrators' report contains no mention of circumstances that would have prevented this. Consequently, we must assume that the initial allocation of licenses was inconsequential for the ultimate distribution of market shares in the EC bananas wholesale trade services market. Those market shares could only have been influenced indirectly through the allocation of the tariff-quota among bananas grown in different non-ACP countries, if, for example, US service providers were more closely linked to Ecuadorian than to Colombian banana producers. However, the arbitrators' report provides no indication that such was the case either. ${ }^{80}$ One must conclude that the US service providers' share of the EC bananas wholesale services market would have been the same in a WTO-consistent regime. Of course, a different initial distribution of licenses would have had important distributional consequences (because the initial license holder receives the purchase price from the ultimate user), but this argument already leads to (b).

As to item (b), the decisive element was one's assumption of how import licenses would be distributed in a WTO-consistent regime (first-come first-serve, past import volume, etc). The arbitrators did not reveal their assumption, such that it is impossible to follow their line of reasoning here. But note that the EC could have chosen to auction off the import licenses to the highest bidder. Under the reasonable assumption of competitive bidding, such an auction would extract all quota rents from private service providers for the benefit of the EC. An auction of import licenses does not discriminate, neither de jure nor de facto, against service providers of a particular country, and it would therefore be consistent with GATS Articles II and XVII. An auction of import licenses for products from specified countries does not affect the various exporting countries' shares of a tariff quota, and is therefore also consistent with GATT Article XIII. ${ }^{81}$ Hence, a plausible WTO-consistent regime would have distributed import licenses in a way that would have eliminated all private quota rents.

In sum, one's best guess as to the real level of impairment of the US is zero. This might seem counterintuitive given how vigorously the US pursued the case, and how vigorously it was lobbied to do so by a certain US trading firm. However, it is well possible that the US and that trading firm were simply hoping to get a bigger slice of the rents resulting from a continued WTO-inconsistent regime, or to push the EC to open up its markets beyond what it was obliged to do under WTO rules (if the minimum WTOconsistent regime was politically unacceptable to the EC).

\section{Ecuador: Level of Impairment}

In the parallel EC - Bananas 22.6 (Ecuador) case, the (identical) arbitrators provided at least a cursory, but still hardly satisfactory, explanation of their estimate of Ecuador's trade losses based partially on past trade. Again, it took 35 pages of preliminary issues

\footnotetext{
${ }^{80}$ But see Nomura, above n 71, at 12, who explains that Chiquita has banana plantations in countries disfavored under the EC regime.

${ }^{81} \mathrm{Cf}$. O'Connor, above n 77 , at 255, pointing out that counting quota rents is contentious because the GATS does not protect quota rents.
} 
(notably DSU Article 22.3) to get to the central issue, which was then disposed off as follows:

We assume the volume of Ecuador's banana exports to the EC would increase (at the expense of other suppliers) to the level of its best-ever exports during the past decade, that the share of those bananas distributed in the EC by Ecuadorian service suppliers would rise to 60 per cent, and that the proportion of those distributed bananas for which Ecuadorian service suppliers are given import licenses would rise to 92 per cent (assuming that the remaining 8 per cent of the available import licenses are those reserved for newcomers, consistent with the assumption used in the US/EC Bananas III arbitration).

Using the various data provided and our knowledge of the current quota allocation and what it would be under the WTO-consistent counterfactual chosen by us, we determine that the level of Ecuador's nullification and impairment is US\$201.6 million per year. ${ }^{82}$

Again, there is no mention of the burden of proof ('we assume' ...). And while it seems plausible (albeit optimistic) to assume that the volume of Ecuador's banana exports to the EC would rise to the historical maximum, the arbitrators' assumption of a $60 \%$ market share for Ecuadorian service suppliers in distributing Ecuadorian bananas within the EC is a guess whose plausibility depends on the actual strength of the Ecuadorian banana distribution services sector (in particular Noboa). Lastly, import licenses and quota rents are subject to the same reservations as in the US case.

All of that being said, there is one issue that could actually have led to a much higher estimate of Ecuador's level of impairment: by the time the arbitrators reached their decision on Ecuador's claim, the Lomé waiver had expired, such that the EC could no longer legally accord a tariff preference to ACP bananas. Of course this would have been immaterial if the relevant point in time for determining the WTO-consistent counterfactual for evaluating permissible retaliation was the expiration of the 'reasonable period of time' for compliance (cf. DSU Article 22.2). But this controversial interpretation of DSU Article 22.2 was not adopted by the arbitrators. ${ }^{83}$ Instead, they simply assumed that the EC would be granted a new waiver by the WTO covering the ACP tariff preference. ${ }^{84}$ (Admittedly, the new (so-called Cotonou) waiver was eventually granted - but only more than one and a half years later. ${ }^{85}$ ) Consequently, the arbitrators

\footnotetext{
${ }^{82}$ EC - Bananas III (Ecuador) (Article 22.6) para 169-170 (footnote omitted); the discussion of DSU Article 22.3 occupies para 42-138, the suspension of obligations under TRIPs para 139-165.

${ }^{83}$ The point has not been directly addressed in WTO decisions or the literature so far. Prior Article 22.6 decisions only had to deal with changing factual circumstances. US - Byrd (EC) (Article 22.6) para 4.20 saw "no limitation in the DSU to the possibility of providing for a variable level of suspension if the level of nullification or impairment also varies.' It distinguished EC - Hormones (US/Canada) (Article 22.6) para 38/37, which merely stated that factual developments due to non-compliance before the expiration of the 'reasonable period of time' could not be assumed away in construction of the counterfactual (this distinction was addressed in Brazil - Aircraft (Article 22.6) para 3.633.65 and Canada - Aircraft Credits and Guarantees (Article 22.6) para 3.67-3.73). US - FSC (Article 22.6) para 2.122.15, while proclaiming agreement with prior decisions that the relevant date for evaluating permissible retaliation was the expiration of the 'reasonable period of time', based its decision on a version of the WTO-inconsistent measure that was enacted two weeks after this date (ibid para 2.12). To avoid unnecessary duplication of proceedings, the better solution would appear to be to rely on the law in force at the close of the Article 22.6 proceeding.

${ }^{84}$ EC - Bananas III (Ecuador) (Article 22.6) para 167 with n 55.

${ }^{85}$ Decision of the Ministerial Conference dated 14 November 2001, WT/L/4371. Also, the decision in particular of Ecuador to agree to the waiver may have been influenced by the arbitrators' decision itself.
} 
were dispensed from the formidable task of calculating prices and import volumes under a global tariff-quota or the like from elasticities, and they could treat the Ecuador case very much like the US case. ${ }^{86}$ This certainly made the arbitrators' life a whole lot easier, but it did not enhance the persuasiveness of their findings. ${ }^{87}$

In sum, while it is impossible to express an opinion on the precise level of impairment of Ecuadorian benefits based on the facts given in the arbitrators' report, the arbitrators' estimate could be correct only by coincidence, not by methodology. ${ }^{88}$

\section{An Alternative (Diplomatic) Explanation}

After all this criticism, the redeeming virtues of the EC - Bananas III (US/Ecuador) Article 22.6 decisions should be mentioned very briefly. Given the history ${ }^{89}$ and high profile of the bananas case, the extraordinary effort with which it was litigated ${ }^{90}$, and the tensions that it raised ${ }^{91}$, it is not certain that the US would have accepted an award refusing its retaliation request in its entirety. The relatively (in relation to overall EC-US trade) small retaliation award may have been the smaller problem in comparison to what would have happened had the US imposed unilateral sanctions in defiance of the arbitrators' award. ${ }^{92}$ And the image of the WTO, in particular in the eyes of developing

\footnotetext{
${ }^{86}$ The arbitrators themselves stressed this consequence of their assumption, see EC - Bananas III (Ecuador) (Article 22.6) para 167-168. Incidentally, one may ask whether the arbitrators' decision in the US case should also have anticipated the expiry of the Lomé waiver by providing for two different levels of suspension, before and after the expiry.

${ }^{87}$ See O'Connor, above $\mathrm{n} 77$, at 254-55.

${ }^{88}$ None of this means that the EC's banana import regime does not hurt Ecuador and possibly depresses imports from Ecuador by much more than the US\$201.6 million per year set by the arbitrators. But the point is that most of that detrimental effect is achieved through measures that are consistent with WTO rules.

${ }^{89}$ For a full overview of the EC - Bananas dispute, see the references above $\mathrm{n} 71$. See in particular the two preceding GATT panel reports European Economic Community - Member States' Import Regime for Bananas, DS32/R, 3 June 1993 and European Economic Community - Import Regime for Bananas, DS38/R, 18 January 1994.

${ }^{90}$ For example, with the two major trading blocks (EC and US) and others as parties and 20 third parties, a third of the entire WTO membership was involved in the litigation, and the original panel alone generated several thousand pages of submissions, see Panel Report, EC - Bananas III, para 7.1. The case generated a stream of decisions, see WTO Appellate Body Report, EC - Bananas III; Award of the Arbitrator Said El-Naggar, European Communities - Regime for the Importation, Sale and Distribution of Bananas - Arbitration under Article 21.3(c) of the Understanding on Rules and Procedures Governing the Settlement of Disputes, WT/DS27/15, 7 January 1998; WTO Panel Report, European Communities - Regime for the Importation, Sale and Distribution of Bananas - Recourse to Article 21.5 by the European Communities, WT/DS27/RW/EEC, 12 April 1999 (not adopted); Panel Report, EC - Bananas III (Ecuador) (Article 21.5). The DSU 21.5 decisions were circulated simultaneously with EC - Bananas III (US) (Article 22.6).

${ }^{91}$ In particular, before the Article 22.6 decision in EC - Bananas III (US) was announced to the parties on 6 April 1999, and a day after it should have been announced under the 60-day time-frame of DSU Article 22.6, the US administration, under pressure from Congress, had already moved to apply retaliatory tariffs, suspending customs clearance for some goods as of 3 March 1999, see Salas \& Jackson, above n 71, at 155, 159. This in turn prompted counter-litigation by the EC, WT/DS152 (US - Section 301) and WT/DS165 (US - Import Measures on Certain EC Products). See the description of the crisis in Salas \& Jackson, above n 71, at 152-60, and Cherise M. Valles \& Brendan P. McGivern, 'The Right to Retaliate under the WTO Agreement - The "Sequencing" Problem', 34 (2) JWT 63 (2000), at 71-77.

92 The award of US\$ 191.4 million was about $36.8 \%$ of the original US request of US\$ 520 million, and about $58.55 \%$ of the lowest US estimate given during the Article 22.6 proceedings, see EC - Bananas III (US) (Article 22.6) para 1.1,
} 
countries, would certainly have suffered enormously if Ecuador, a developing country that contrary to the US actually exported bananas, had been refused retaliation after the US' grant. ${ }^{93}$ Whether the arbitrators thought of any of this when making their decision will forever remain their secret, but if they had, their decisions could have been called 'diplomatic lawyering' at its best. ${ }^{94}$

\section{EC - Hormones (US/Canada) (Article 22.6)}

\section{The Case}

Canada and the US had attacked an EC ban on the importation and sale for human consumption of meet from animals that had been administered any of six particular hormones for growth-promoting purposes. The panel and the Appellate Body found that the EC ban violated WTO rules because it was not based on a risk assessment as required by Article 5.1 of the Agreement on the Application of Sanitary and Phytosanitary Measures ('SPS'). ${ }^{95}$

The ban affected two types of meet product exports to the EC from Canada and the US, where use of the 6 hormones in question was common. These products were highquality beef ('HQB') and edible beef offal for human consumption ('EBO'). Except for the ban, EBO could be imported into the EC in unlimited amounts subject only to a tariff ranging from 0 to $4 \%$ ad valorem. ${ }^{96}$ By contrast, importation of HQB was administered under a tariff-quota system, with Canada and the US sharing a bound tariff-quota of 11,500 tons of annual imports at $20 \%$ ad valorem tariffs, and out-of-quota tariffs set at prohibitive rates. $^{97}$

\section{Level of Impairment: The Arbitrators’ Approach}

Following the EC - Bananas III (US) (Article 22.6) precedent, the arbitrators determined impairment through trade effects by comparing actual EC imports from Canada and the

7.5. Cf. Hudec, above $\mathrm{n} 3$, at 25 , who thinks that the lack of scientific explanation did not matter as long as the decision 'looked objective enough to persuade the relevant audiences in both countries that a neutral tribunal had made an objective judgment of equivalence.'

${ }^{93}$ In any event, Ecuador was unlikely ever to implement its sanction award, and indeed it never did.

${ }^{94}$ The uneasy position of the WTO dispute settlement system between diplomacy and lawyering is described by Joseph H.H. Weiler, 'The Rule of Lawyers and the Ethos of Diplomats', 35 JWT 191 (2001); and the political constraints on WTO adjudication are highlighted by Richard H. Steinberg, 'Judicial Lawmaking at the WTO - Discursive, Constitutional, and Political Constraints', 98 AJIL 247 (2004).

${ }^{95}$ For one of the many reviews of these decisions see, e.g., Christophe Charlier \& Michel Rainelli, 'Hormones, Risk Management, Precaution and Protectionism: An Analysis of the Dispute on Hormone-Treated Beef between the European Union and the United States', 14 European Journal of Law \& Economics 83 (2002).

${ }^{96}$ See EC - Hormones (US/Canada) (Article 22.6) para 66/57.

${ }^{97}$ See EC - Hormones (US/Canada) (Article 22.6) para 48/44. The EC schedules explicitly reserved a tariff-quota of only 10,000 tons for Canada and the US (see Schedule LXXX, European Communities, Part I: Most-Favored Nation Tariffs, Section 1: Agricultural Products, Section 1-B: Tariff Quotas), but the EC was arguably under a duty to raise that quota to 11,500 under GATT Article XXIV.5(b) following the accession of Austria, Finland and Sweden. 
US (actual trade) with what they would be had the ban been lifted by the end of the implementation period (DSU Article 21.3) (potential trade):

\section{a) Potential Trade}

For potential trade in HQB, the arbitrators based their calculation on the assumption that but for the ban, the Canadian/US tariff quota would be fully utilized, as were other suppliers' tariff quotas. ${ }^{98}$ Hence, potential trade could be calculated for each country as (total tariff quota) $*$ (share of tariff quota) $*$ (average price). The respective tariff quota shares of Canada and the US were derived from the ratios of Canadian to US overall beef exports and market shares in third countries and the EC. These all lay between 4/96 and $10 / 90$, and the arbitrators, taking into account an upward trend in these ratios in the preceding years, retained 8/92 as a reasonable number. ${ }^{99}$ Price was derived by increasing the current average price of EC HQB imports from the US by some amount to account for an expected shift to high quality cuts if the ban were lifted, and, for Canada, by an additional amount to account for the consistently higher prices of Canadian exports as compared to US exports; a methodology in determining those additional amounts was lacking or not disclosed. ${ }^{100}$

For potential trade in EBO, no upper quantity limit in the form of a tariff quota existed. Here, the arbitrators' calculated the quantity of each country's (US/Canada) potential trade (in 1999) as the average of their respective pre-ban annual exports to the EC in 1986-1988, reduced in proportion to the decline in the EC's apparent consumption between 1989-1991 and 1995-1997 as a result of the BSE crisis. ${ }^{101}$ The price was set at the level suggested by the US, which was similar to the EC's and higher than Canada's

\footnotetext{
${ }^{98}$ See EC-Hormones (US/Canada) (Article 22.6) para 55/46.

${ }^{99}$ EC - Hormones (US/Canada) para 56-58/ 47-49. Cf. GATT Article XIII.

${ }^{100}$ Cf. EC - Hormones 22.6 (US/Canada) para 59-61/50-52.

${ }^{101}$ EC - Hormones (US/Canada) (Article 22.6) para 67-68/58-59 (the reference to BSE is in para 32/31). In calculating the reduction in apparent consumption (production + imports - exports), the arbitrators thought they had to confront the complication that consumption had been reduced as a consequence of the ban itself, as documented by the decline between the years 1988 and 1989, when the ban was introduced. It seems that the best proxy for isolating the change in apparent consumption caused by changing tastes (as opposed to by the ban) would have been the ratio of the post-ban figures of apparent consumption for 1995-97 to those for 1989-91. The arbitrators chose instead to calculate the ratio of pre-ban apparent consumption in 1986-88 to post-ban apparent consumption in 1995-97, but with actual values for 1995-97 augmented by the average of the differences between the actual import volumes and the annual trend import volumes (as extrapolated from pre-ban figures 1981-88) for 1989-91. This raises various objections. First, it is unclear how the arbitrators calculated trend import volumes. Second, while the ban undoubtedly prevented some imports, some of these imports would have been substituted by domestic production, such that adding lost imports to remaining apparent consumption overstates potential apparent consumption. Third, and most importantly, adding a constant figure of lost imports calculated in a period of high demand (1989-91) to remaining consumption in a period of low demand (1995-97) implicitly assumes that imports would have been constant from 1989 to 1997 regardless of demand. This assumption is unreasonable (consider the extreme case of zero remaining consumption!) and will most likely overstate potential imports and thus potential apparent consumption. Above all, it is an assumption (constant lost imports) that contradicts the very purpose and underlying assumption of the analysis, which is that potential imports were lower in 1995-97 than in 1989-91, the question being how much!
} 
suggestion, but $30 \%$ lower than the 1996-1998 average price to reflect the increase in supply if the ban were lifted. ${ }^{102}$

\section{b) Actual Trade}

Actual trade in HQB could generally be read from then current trade statistics. However, in 1999, the EC had introduced a 'test and hold' procedure for US beef imports to screen for hormone residuals. Taking export certificates as proof, the US argued that its beef exports had further declined by 75 to $98 \%$ as a result; the EC denied any effect except delay. The arbitrators thought that the burden of proof for this specific fact was on the US, considered that the drop in trade flows might be temporary and about to normalize following consultations between the parties, but opined that nevertheless there might be a dampening effect on imports. The arbitrators then quantified this effect at $25 \%$ without further argument. ${ }^{103}$

\section{Level of Impairment: Some Problems}

Evaluating a counterfactual cannot yield more than a 'reasoned estimate.' 104 But some logical inconsistencies in the arbitrators' calculations, and potentially profound objections as to their choice of counterfactual, cast doubt on whether even this limited goal was achieved, even though the former are not serious and unidirectional enough, and the latter too controversial, to conclude that EC - Hormones (US/Canada) (Article 22.6) was wrong as other Article 22.6 decisions were. ${ }^{105}$

For an example of logical inconsistencies, consider the arbitrators' treatment of EBO used for pet food. ${ }^{106}$ This was unaffected by the ban and the changes in consumer taste, so that in the arbitrators' world without substitution effects, the relative amount of EBO imports for pet food should have risen while their absolute amount should have stayed constant. $^{107}$ However, what was supposed to be 322 tons of annual EBO imports from Canada for pet food in 1986-88 was down to 2 tons in 1996-98. ${ }^{108}$ And the arbitrators reduced their end-results of trade effects by the ostensible percentage of EBO imports

${ }^{102}$ EC-Hormones (US/Canada) (Article 22.6) para 70/61.

${ }^{103}$ See EC - Hormones (US) (Article 22.6) para 27-28, 45-47.

${ }^{104}$ EC - Hormones (US/Canada) (Article 22.6) para 41/40, cf. para 42-43/41-42.

${ }^{105}$ McGivern, above $\mathrm{n} 3$, at 151 thinks that a change in any of the arbitrators' assumptions would have led to very different results; cf. similarly Breuss, above n 51, at 285 (calling some assumptions 'arbitrary').

${ }^{106}$ Another striking examples is discussed above in n 101. Cf. Bernstein \& Skully, above n 3, at 392-96, discussing some other aspects of the arbitrators' calculation, with similar conclusions.

107 The problem was that trade statistics did not disaggregate EBO for human consumption and for pet food. Based on the burden of proof, the arbitrators found that $10 \%$ and $5 \%$, respectively, of EC EBO imports from Canada and the US were used for pet food, EC - Hormones (US/Canada) (Article 22.6) para 75/66 (the EC maintained that 31.5\% of EBO imports were used for pet food, while Canada suggested $10 \%$ and the US 5\%; none of these figures were supported by evidence).

${ }^{108}$ See EC - Hormones (Canada) (Article 22.6) para 60 and Annex I. 
used for pet food ${ }^{109}$, which implicitly and incorrectly assumed that EBO for pet food and human consumption were equally affected by the ban, and that their proportions remained constant. ${ }^{110}$ Perhaps the difficulties in arriving at a consistent counterfactual are insurmountable. But the arbitrators could arguably have avoided to make them their difficulties if they had not decided 'to make their own estimate, on the basis of all arguments and evidence submitted by the parties' once they found neither party's approach convincing. ${ }^{111}$ In fact, none of the above might have mattered had the arbitrators strictly enforced the burden of proof on the EC and not rejected without discussion Canada's model based on (current) demand, expenditure, marginal rates of substitution and so on that led to 1.5 times higher estimates of lost trade. ${ }^{12}$

Of more systemic relevance are objections regarding the arbitrators' counterfactual. ${ }^{113}$ Why should compliance have led the EC to (a) lift the ban on imports of hormone-treated beef, while (b) maintaining the ban on the use of the relevant growth hormones in domestic beef production, as the arbitrators' calculations assumed? As to (a), the EC could have complied with the WTO's rulings by reaffirming the ban based on a risk assessment in conformity with the requirements of SPS Article 5. ${ }^{114}$ As to (b), it is not obvious why the EC would have maintained a reverse-discriminatory ban for domestic production for reasons of consumer protection once the consumer market was served with hormone-treated imports anyway; had the EC lifted the domestic ban, European domestic

109 Ibid.

${ }^{110}$ The direction and size of the resulting error is not clear. The final step of the arbitrators' analysis (multiplying the difference between actual and potential imports by the constant share of EBO imports for human consumption) is unwarranted and leads to an underestimation of trade effects: if both actual and potential imports contain the same constant absolute amount of EBO imports for pet food, the difference between the two reflects only changes in imports of EBO for human consumption anyway. But the mistake lead to an overestimation while factoring the decline in apparent consumption of EBO into the calculation of potential trade: the change in consumer tastes affected only EBO for human consumption, such that lumping it together with EBO for pet food underestimated the decline in apparent consumption of EBO used for human consumption, which in turn lead to an overestimation of the potential market for EBO for human consumption. Calculation of the aggregate effect is not possible on the basis of the disclosed data (backward calculation is not possible, notably because of the error discussed above $\mathrm{n} 101$ ).

${ }^{111}$ Cf. EC - Hormones (US/Canada) (Article 22.6) para 35/34. The arbitrators maintained that '[i]n doing so, we follow the rules on burden of proof ...'

${ }^{112}$ Cf. EC - Hormones 22.6 (Canada) para 26-28 (Canada), 32 (EC) and 34, 58-60 (arbitrators).

113 O'Connor, above n 77, at 256 objects, regarding HQB, that it should not have been assumed that the 11,500 tons tariff quota was to be divided solely between Canada and the US. GATT Article XIII commands, of course, that tariff quotas be allocated in a non-discriminatory matter. However, given that Australia, Argentina, and Uruguay had all been allotted a separate quota in the EC schedule and that the only remaining big beef producer, Brazil, was apparently granted its own tariff quota by the EC even though it was not in the schedules (cf. EC - Hormones (US/Canada) (Article 22.6) para 55/46), the 11,500 tariff quota may just have corresponded to what Canada and the US were entitled to under GATT Article XIII.

${ }^{114}$ As they claim they now did, see Communication by the EC, WT/DS26/22 and WT/DS48/20, 28 October 2003, and the proceedings WT/DS/320 and 321 initiated by the EC against the ongoing retaliation by the US and Canada, respectively. Cf. Petros C. Mavroidis, 'The Trade Disputes Concerning Health Policy Between the EC and the US', in Ernst-Ulrich Petersmann \& Mark A. Pollack (eds), Transatlantic Economic Disputes, (Oxford: Oxford University Press 2003) 233, at 242, arguing that the EC could have invoked SPS Article 5.7 to win the original case on the merits - but if the EC lost only because of this formality, what is the real loss of Canada and the US sustained as a consequence of the ban? 
production would have soared, potentially leading to a reduction in imports. ${ }^{115}$ It is deceptively easy to dismiss this criticism by defining the appropriate counterfactual as being identical to the real situation 'but for' the removal of the WTO-inconsistent measure at issue. If 'measure' in this definition meant the particular legislative or administrative act, should the amount of permissible retaliation really depend on whether the import ban is contained in a separate act or covered by an overall ban ('all sales and uses of X are prohibited')? Alternatively, one might argue that the counterfactual must remove only the minimum part required to make the act at issue WTO-conform. But first of all there may be more than one way to do this (for example, discrimination could be eliminated by better treatment of imports or worse treatment of domestic goods). Second, why would we do this? ${ }^{116}$ An 'amputation' counterfactual would usually lead to impairment measures higher than what the complaining Member really suffers as a result of the responding Member's policy. Whether or not this is desirable would, again, seem to depend on the purpose of retaliation, which is, of course, unclear.

\section{US - 1916 Act (EC) (Article 22.6)}

\section{The Case}

In US - 1916 Act, the EC and Japan had attacked a US statute enacted in 1916 (the 'Act'). ${ }^{117}$ The Act made it unlawful to sell imports at prices substantially below their home-country or third country market value (plus freight and duties incurred in importing to the US) with the intent of injuring an existent or nascent domestic US industry. The Act provides for criminal sanctions, as well as a civil right of action for injured US businesses to recover treble damages and litigation cost. The Panel and the Appellate Body found that the Act violated various provisions, most importantly by providing for anti-dumping remedies not permissible under the WTO agreements. ${ }^{118}$

\footnotetext{
${ }^{115}$ Of course, fiscal reasons related to the Common Agricultural Policy might have caused the EC to keep the ban, see O'Connor, above n 77, at 252.

${ }^{116}$ A more extensive exposition of the argument alluded to here would parallel the concept of the 'scope of the rule' theory in torts law, cf. A. M. Honoré, 'Causation and Remoteness of Damages', in André Tunc (ed), International Encyclopedia of Comparative Law vol. XI/1 (Tuebingen et al: J.C.B. Mohr (Paul Siebeck) and Martinus Nijhoff Publishers 1981), ch. 7 para 97.

117 Title VIII of the Revenue Act of 1916 (heading 'Unfair Competition'), 15 United States Code (USC) §72 (2000), now repealed by Pub.L. 108-429, Title II, § 2006(a), Dec. 3, 2004, 118 Stat. 2597.

118 The principal violations were thus of GATT Article VI.2 and Article 18.1 of the Agreement on Implementation of Article VI of The General Agreement on Tariffs and Trade 1994 ('Anti-Dumping Agreement'), see WTO Panel Report, United States - Anti-Dumping Act of 1916 - Complaint by the European Communities (US - 1916 Act (EC)), WT/DS136/R, adopted 26 September 2000, para 6.183-6.205; WTO Panel Report, United States - Anti-Dumping Act of 1916 - Complaint by Japan (US - 1916 Act (Japan)), WT/DS162/R, adopted 26 September 2000, para 6.201-6.231; WTO Appellate Body Report, United States - Anti-Dumping Act of 1916 (US - 1916 Act), WT/DS136/AB/R and WT/DS162/AB/R, adopted 26 September 2000, para 136-138. Furthermore, the Act violated GATT Article VI.1 and Article 3 of the Anti-Dumping Agreement by not requiring a finding of material injury, or threat thereof, before any sanctions could be imposed (Panel Report, US - 1916 Act (EC/Japan), para 6.178-6.181/6.251-6.254), and did not observe the procedural requirements of Articles 4, 5.1, 5.2, 5.4 and 5.5 of the Anti-Dumping Agreement (para 6.2126.216/6.255-6.261). Surprisingly, most of the proceedings and subsequent critique of the decisions turned on the question whether the Act fell within the scope of GATT Article VI and the Anti-Dumping Agreement, see Panel
} 
It is unclear what role the Act plays in trade practice. Apparently, there had never been a criminal conviction by the time of the arbitrators' decision, and civil judgments against importers were rare, the first treble-damages award having been entered in 2003 (against a Japanese company). ${ }^{119}$ Not a single judgment had ever been rendered against an EC importer under the Act. ${ }^{120}$ However, the EC and Japan pointed to numerous settlements that European and Japanese importers had been forced to enter into under threat of litigation. ${ }^{121}$ They also pointed more generally to the chilling effect that, in their opinion, the Act exerted on importers' business behavior. ${ }^{122}$ The problem was that these effects of the Act were exceedingly hard to measure. This is obvious for the chilling effect (especially given that the Act had been on the books for over 80 years). Less obviously, it was also true for the transfer payments under the forced settlements, because the American parties to these settlements generally objected to disclosure of their terms including the amount of money that importers agreed to pay. ${ }^{123}$

\section{2. 'Mirror Legislation' and the Different Ways of Showing Equivalence}

These measurement problems made it difficult to come up with a measure of impairment that could be used to ensure equivalence with the authorized level of suspension. ${ }^{124}$ The solution suggested by the EC was elegant and simple: don't measure. Instead, the EC requested authorization to implement so-called 'mirror legislation' in the EC targeting only US importers, i.e., EC legislation mostly identical to and on some points less stringent than the Act. ${ }^{125}$ This was convincing. Qualitatively, the levels of suspension and impairment could be said to be equivalent simply because the measure of suspension ('mirror legislation') was identical to (or less than) the WTO-inconsistent measure giving rise to impairment. ${ }^{126}$ Quantitatively, the levels of suspension and impairment could be

Report, US - 1916 Act (EC/Japan), para 6.93-6.177/6.108-6.200; Appellate Body Report, US - 1916 Act, para 103133; and compare the critique of Richard O. Cunningham \& Troy H. Cribb, 'Dispute Settlement Through the Lens of Free Flow of Trade', 6 JIEL 155 (2003), at 159. But if the Act had not fallen within the scope of GATT Article VI and the Anti-Dumping Agreement, its violation of the national treatment principle as laid down in GATT Article III.4 would have been plain (because only importers are subject to the Act's prohibitions, while only domestic producers are protected).

${ }^{119}$ See US - 1916 Act (EC) (Article 22.6) para $6.11 \mathrm{n} 87$.

${ }^{120}$ See US - 1916 Act (EC) (Article 22.6) para 6.5.

${ }^{121}$ See US - 1916 Act (EC) (Article 22.6) para 6.8.

${ }^{122}$ See US - 1916 Act (EC) (Article 22.6) para. 2.6

${ }^{123}$ Cf. US - 1916 Act (EC) (Article 22.6) para. 6.8-6.9.

${ }^{124}$ Howse \& Staiger, above n 12, at 312-13, approve of the arbitrators' exclusion of the 'chilling effect' from the calculation, because they find this exclusion prudent given the inherent uncertainties involved in quantifying such effects. They do not exploit the symetry of the proposed EC measure as the present article does.

${ }^{125}$ Unlike the Act, the proposed EC legislation did not provide for criminal sanctions, purportedly complied with the procedural provisions of Article 5 of the Anti-Dumping Agreement, and did not envisage to pay out the collected treble damages to private EC firms; see US - 1916 Act (EC) (Article 22.6) para 2.7, 2.9. It seems that there was one material difference: the EC mirror legislation was to be administered by EC authorities, rather than granting private rights of action to be enforced by the courts. This might have led to different (higher?) levels of enforcement. But neither the parties nor the arbitrators focused on this difference.

${ }^{126}$ See Howse \& Staiger, above n 12, at 297-98 ('normative equivalence'). 
said to be equivalent because identical measures will ceteris paribus have identical effects, including on trade. ${ }^{127}$ In other words, even though the numerical values for the trade effects of the two measures were not known, their quantitative equivalence was assured by the definition of suspension (i.e., via a proxy). Of course, asymmetrical conditions on different sides of the Atlantic could make for asymmetric effects, but given the general applicability of the Act and the 'mirror legislation', this was unlikely, and in any event, under the rules on burden of proof used by Article 22.6 proceedings, any such asymmetry would have had to be proven concretely by the US. ${ }^{128}$ The last point has more general implications: Based on the burden of proof, quantitative equivalence should have been found as a default simply because, given the insurmountable measurement problems, the US was unable to prove the contrary (even if quantification was required, the EC could just have put forward an arbitrary number).

The arbitrators' rejection of the EC request marks a low point in WTO jurisprudence. Of the two arguments used to reject the qualitative equivalence approach, one was circular and the other frivolous. ${ }^{129}$ Granted, it is perhaps understandable that the arbitrators desired to maintain continuity with prior Article 22.6 decisions and thus favored a quantitative approach to equivalence based on trade effects. ${ }^{130}$ But the further decisive requirement that the levels of suspension and impairment had to be (individually) numerically quantified was not based on precedent, and the argument given was a logical fallacy: ${ }^{131}$ It is simply not true that 'a determination of the trade or

\footnotetext{
${ }^{127}$ Obviously, insofar as the actual effect of a measure is always to some extent dependent on chance, the argument is only true ex ante (equal probabilities of consequences for both measures). But this could be said of the equivalence of any suspension measure (because the actual effects of the chosen suspension and of the ongoing violation will depend on future trade flows that can be predicted only stochastically).

${ }^{128}$ See US - 1916 Act (EC) (Article 22.6) para 5.69 n 74 (chilling effect of both measures unknown and uncertain but identical); compare the general rules on burden of proof as set out by US - 1916 Act (EC) (Article 22.6) para 3.4; accord the other Article 22.6 decisions, above Section III.A. The US did not attempt to prove concrete differences leading to greater trade effects of the 'mirror legislation', and it should not have been an easy case to make. As is well known, the EC exports more to the US than the US exports to Europe, such that the 1916 Act should have greater effects than the EC 'mirror legislation'. Also, most imaginable asymmetries in EC-US trade would result in impact asymmetries much smaller than any of the measurement errors tolerated in the EC - Bananas and EC - Hormones DSU Article 22.6 arbitrations. Lastly, the EC had built in a 'buffer' against aggravating circumstances in the EC by making the EC regulation less stringent on some points, cf. above $\mathrm{n} 125$.

${ }^{129}$ The circular argument was that identical measures can have different effects in different circumstances (US - 1916 Act (EC) (Article 22.6) para 5.32, 7.5, also cf. 5.21, 6.1,7.1) - but the question was precisely if effects even need to be considered! The frivolous argument was the first sentence of DSU Article 22.7. It prohibits arbitrators from examining 'the nature of the concessions or other obligations to be suspended.' (emphasis added) According to the arbitrators, this provision barred them from conducting the close examination of the 'mirror legislation' that would be required to ensure its qualitative equivalence with the WTO-inconsistent US measure, ibid, para 5.40-5.42, 7.4. But the cited provision does not say anything about the arbitrators' examination of measures. The context of the provision indicates that all it is concerned with is to prevent arbitrators from interfering with the complaining Member's choice of concessions or obligations to suspend (e.g., tariff concessions for which product, TRIPS Agreement obligations instead of GATS obligations, etc) (which also means that there can never be a problem if the complaining Member itself asks the arbitrators to examine its proposed suspension measure). And the cited first sentence of DSU Article 22.7 concludes: 'but shall determine whether the level of such suspension is equivalent to the level of nullification and impairment.'

${ }^{130} \mathrm{Cf}$. the reference above $\mathrm{n} 27$.

131 The arbitrators claimed to find support for their position in other decisions, cf. US - 1916 Act (EC) (Article 22.6) para 5.24-5.28. But this was condemned to be futile, as the question had never arisen in prior arbitrations. Passages in
} 
economic effects of the 1916 Act on the EC in numeric or monetary terms ... is the only way in which the arbitrators can determine "equivalence" in the present context" ${ }^{\prime 32}$ - in order to ensure equivalence of two variables, it is sufficient to know that they are both equivalent to some third variable. ${ }^{133}$ Having thus fallaciously dismissed both qualitative and quantitative arguments for equivalence, the arbitrators perverted their own rules on burden of proof to deprive the EC of its last resort, equivalence by default: It was enough for the US to raise the abstract possibility of asymmetric effects of identical measures under asymmetric circumstances to make a prima facie case that the trade effects of the 'mirror legislation' were not equivalent to those of the Act. ${ }^{134}$ But if the truism that a fact is uncertain is enough to 'shift' the burden of proof, the burden of proof is inversely distributed from the outset! ${ }^{135}$

Unable to prove any concrete numerical level of chilling effect, settlement payments, or litigation cost under the Act (there had been no judgments against EC companies), the EC obtained authorization to suspend obligations and concessions only if and to the extent that future judgments entered into against, or settlements accepted by, EC exporters under the Act would disclose the amount the EC exporters would have to pay. ${ }^{136}$ Thus, for all practical matters, the EC's request for authorization to suspend concessions and obligations was rejected in its entirety. ${ }^{137}$

other decisions expressing a need to quantify the level of impairment only meant that in those cases (where "mirror legislation' was not at issue) quantification was the only possibility to ensure equivalence. Cf. US - Byrd (EC) (Article 22.6) para 3.37 ('in this case').

${ }^{132}$ US - 1916 Act (EC) (Article 22.6) para 5.23, 7.2, see also para 5.34, 5.69-5.72 and 5.77, where the arbitrators maintained that in order to be included in the calculation of equivalence, an effect needed to be quantifiable.

${ }^{133}$ More precisely, to know that $f(a)=f(b)$, it is enough to know that $a=b$, so that if $f(x)$ denotes (a vector of) the expected consequences of a certain measure and $a$ and $b$ denote (vectors translating) the 1916 Act and the "mirror legislation', respectively, $a=b$ ensures that $f(a)=f(b)$, even though we have no idea what the numerical value of $y=$ $\mathrm{f}(\mathrm{a})=\mathrm{f}(\mathrm{b})$ is.

${ }^{134}$ See US - 1916 Act (EC) (Article 22.6) para 5.13-5.16, 5.30-5.35.

${ }^{135}$ Probably without realizing it, the arbitrators said as much themselves in different words: 'The Arbitrators cannot simply assume ... that the EC suspension will always have 'similar, or in fact less burdensome economic facts than the 1916 Act.' (US - 1916 Act (EC) (Article 22.6) para 5.33 (emphasis in original)).

The arbitrators also used (or rather abused) the ancillary theories of the burden of proof for specific alleged facts (ibid, para 6.11 (settlements)) and the mantra of 'too speculative, too remote' (ibid, para 5.69 (chilling effect), 6.10 (undisclosed settlements), 5.54-5.57 (generally)). Invoked against the party bearing the burden of proof, they are just verbal variations of that fundamental concept. Inversely, if the EC had not borne the initial burden of proof for a certain level of impairment, it could not have been said that it is basing its claim on specific facts (such as the chilling effect) such that it should bear the burden of proof for them (which amounts to the same as saying that the US, Canada and Ecuador should have borne the burden of proving each ton of lost bananas/beef trade in the EC - Bananas and EC - Hormones cases). For litigation costs, the arbitrators also invoked the unsatisfactory argument that such costs had never been taken into consideration in previous Article 22.6 proceedings (unsurprisingly, since suspension authorization relating to litigation cost had never been requested in prior proceedings), ibid, para 5.76.

${ }^{136}$ See US - 1916 Act (EC) (Article 22.6) para 8.1-8.2.

${ }^{137}$ Juergensen, above n 3, maintains that the arbitrators, by not looking at the EC 'mirror legislation', implicitly gave a 'green light' for it, as if the EC could then decide for itself whatever 'value' that legislation had. This is almost certainly an incorrect reading of the decision. The arbitrators repeatedly insisted that the suspension measure 'as applied' must not exceed the (measurable) level of impairment, i.e., the level zero at the time of the decision. As Juergensen himself recognizes, the arbitrators thereby introduced a quantitative ceiling on any EC 'mirror legislation'. So even if the EC could arguably have put a 'mirror legislation' on the book, any actual application of that law that lead 


\section{An Alternative (Political Economy) Explanation}

One may hope that a hidden political economy rationale drove the decision: do not allow suspension that raises trade barriers but does not create a domestic constituency for compliance. ${ }^{138}$ Like the Act, the 'mirror legislation' would have applied to all imports from the US, but each US exporter would have suffered only small expected damage. Consequently, each US exporter would have had only minimal incentives to engage in lobbying for a repeal of the Act to ensure, in turn, repeal of the EC mirror legislation. Perhaps some general business association with broad membership might have overcome this collective action problem, but it is unlikely that they would have pursued the case as vigorously as a small group of exporters of a certain product that has been hit with prohibitive tariffs, perhaps driving these exporters into bankruptcy. As a result, the EC mirror legislation was unlikely to achieve a repeal of the Act, while placing an additional burden on trade indefinitely.

\section{E. US - Byrd (Article 22.6)}

\section{The Case}

The Continued Dumping and Subsidy Offset Act, better known as the Byrd Amendment, was passed in October 2000. ${ }^{139}$ It provides for the distribution to domestic US producers of anti-dumping and countervailing duties collected on imports ('continued dumping and subsidy offset', 'CDSO'). ${ }^{140}$ In order to qualify for CDSO, a domestic producer must fulfill three conditions. First, the producer and any acquirer of the producer must have supported before the US International Trade Commission ('ITC') the petition with respect to which the respective anti-dumping or countervailing duties order has been entered into. ${ }^{141}$ Second, the producer must continue the production of the products concerned. ${ }^{142}$ Third, the producer must certify to the US customs authorities 'qualifying expenditures' (which include most types of production expenses except wages) incurred after the order and 'related to the production of the same product that is the subject of the

to a known payment by US importers would have lead to an 'application' of the legislation in excess of the level of impairment as defined by the arbitrators. The only thing that can be said about the EC position is that the adoption and application of an EC 'mirror legislation', while WTO-illegal, would not have given rise to a retaliation award. This follows directly from the denial of sanctions in reaction to the symmetric US 1916 Act.

${ }^{138}$ Cf. Nzelibe, above n 3, and Goldstein, above n 39, for a general exposition of the idea of designing and using retaliation to activate free-trade (exporting) domestic interest groups in the responding Member.

13919 USC $\$ 1675$ c (2000). The genesis of the Byrd Amendment is explained by Kara M. Reynolds \& Benjamin Liebman, 'The Returns from Rent-Seeking: Campaign Contributions, Firm Subsidies, and the Byrd Amendment', working paper, http://www.ssrn.com (visited 2 August 2005), at 3-6.

${ }^{140} 19$ USC $\$ 1675 \mathrm{c}(\mathrm{a})(2000)$.

${ }^{141} 19$ USC $\$ 1675 \mathrm{c}(\mathrm{b})(1)(\mathrm{A})(2000)$.

14219 USC $\S 1675 \mathrm{c}(\mathrm{b})(1)(\mathrm{B})(2000)$. 
related order.' ${ }^{143} \mathrm{CDSO}$ is distributed in proportion to certified 'qualifying expenditures' net of any CDSO distributed on them previously. ${ }^{144}$

The EC and ten other WTO Members requested a WTO Panel to rule on the WTOconsistency of the Byrd Amendment. ${ }^{145}$ The Panel's principal holding was that CDSO constituted specific action against dumping and subsidies not contemplated by the GATT, the Anti-Dumping Agreement and the SCM, and as such was impermissible under Article 18.1 of the Anti-Dumping Agreement and SCM Article 32.1. ${ }^{146}$ On appeal, the Appellate Body upheld this holding of the Panel. ${ }^{147}$ By contrast, the Appellate Body reversed the Panel's holding that the Byrd Amendment also violated the requirement of minimum domestic industry support for the initiation of an anti-dumping / countervailing duty investigation in Article 5.4 of the Anti-Dumping Agreement and SCM Article 11.4. ${ }^{148}$

\section{Level of Impairment: The Arbitrators’'Approach}

In a courageous departure from previous Article 22.6 proceedings, the arbitrators had asked the parties to submit economic models. These were to be based (only) on the (simplistic) assumption that CDSO operated like a (cost-based? quantity-based?) domestic subsidy. ${ }^{149}$

The US submitted a three-country partial-equilibrium Armington model. ${ }^{150}$ From an economic point of view, the only discernable problem with the US model was that an Armington model assumes competitive markets, while in theory dumping should be found, and thus CDSO should operate, only in oligopolistic markets. ${ }^{151}$ The arbitrators,

\footnotetext{
14319 USC $§ 1675$ c(b)(4) (2000); 19 Code of Federal Regulations (CFR) §159.61(c) (2004).

${ }^{144} 19$ USC $\S 1675 \mathrm{c}(\mathrm{d})(3)(2000) ; 19$ CFR § 159.61(b)(2) (2004).

145 The other Members were Canada, Australia, Japan, Korea, Indonesia, Thailand, India, Brazil, Chile and Mexico.

146 See WTO Panel Report, United States - Continued Dumping and Subsidy Offset Act of 2000 (US - Byrd), WT/DS217/R and WT/DS234/R, adopted 27 January 2003, para 8.1.
}

${ }^{147}$ See WTO Appellate Body Report, United States - Continued Dumping and Subsidy Offset Act of 2000 (US - Byrd), WT/DS217/AB/R and WT/DS234/AB/R, adopted 27 January 2003, para 318.

${ }^{148}$ Cf. Panel Report, US - Byrd, para 7.42-7.46, 7.59-7.66; Appellate Body Report, US - Byrd, para 281-299. Jagdish Bhagwati \& Petros C. Mavroidis, 'Killing the Byrd Amendment with the Right Stone', 3 World Trade Review 119 (2004) and Youngjin Jung \& Sun Hyeong Lee, 'Legacy of the Byrd Amendment Controversies: Rethinking the Principle of Good Faith', 37 JWT 921, 925-38, 954-56 (2003) criticize this holding as formalistic, while John Greenwald, 'WTO Dispute Settlement: An Exercise in Trade Law Legislation?', 6 JIEL 113 (2003), at 120-22 thinks the Byrd Amendment should have been upheld, primarily based on Art. 17.6(ii) of the Anti-Dumping Agreement.

${ }^{149}$ See US - Byrd (EC) (Article 22.6) para 3.80. The US model assumed an ad valorem subsidy, see United States, Answers to the Arbitrators' Questions to the Parties, 28 April 2004, http://www.ustr.gov/Trade_Agreements/Monitoring_Enforcement/Dispute_Settlement/WTO/Section_Index.html (visited 8 December 2004), para 20. Both parties initially shied away from modeling, cf. US - Byrd (EC) (Article 22.6) para 3.82-3.83 (US) and 3.95-3.96 (requesting parties).

150 Cf. US, Answers, above n 149, para 19, following Paul Armington, 'A Theory of Demand For Products Distinguished By Place of Origin', IMF Staff Papers, 1969, 16, at 159-78 (cited from US, ibid).

${ }^{151}$ On the assumptions of an Armington model see US, Answers, above n 149, para 19; on the oligopolistic market structure necessary to provide an economic rationale (if any) for dumping and anti-dumping cf. Michael J. Trebilcock \& Robert Howse, The Regulation of International Trade, (2d. ed., London / New York: Routledge 1999) 177-186. The question of how CDSO really operates, i.e., pass-through, is bracketed here and discussed below. 
however, only took issue with something entirely different. To them, the problem of the US model was that sufficient input data to operate the model was available only for 21 out of 66 country-product-year data points. ${ }^{152}$ This criticism is not well founded statistically, however, because an unbiased sample of 21 observations out of a population of 66 members yields a pretty good estimate of the population mean (and the result of the model could not be more than an estimate anyway). ${ }^{153}$ Moreover, the only indication of sample bias in the arbitral award, the exclusion of de minimis cases by the US, would result in an overestimation of trade effects (to the detriment of the US). ${ }^{154}$ Ignoring this, the arbitrators preferred the requesting parties' 'model', even though they thought that the US model was 'well accepted in the literature" 155 , while no theoretical foundation was provided for the requesting parties' 'model'. ${ }^{156}$ It seems that the only reason for adopting that 'model' was that the US had not loudly protested against it. ${ }^{157}$

The requesting parties' 'model' for calculating reduction in imports (based on the assumption of $100 \%$ pass-through, see below) was $\eta * S * R$, where $\eta$ is the elasticity of substitution $^{158}, \mathrm{~S}$ is the total amount of CDSO, and $\mathrm{R}$ is the 'import-penetration rate' (= value of all imports divided by the value of all domestic shipments). ${ }^{159}$ To repeat, neither the requesting parties nor the arbitrators tried to provide a theoretical foundation for this 'model', and they could not have done so because this 'model' is wholly inadequate. It is enough to note that the 'model' uses absolute amounts, rather than 'looking at the margin' using the relevant elasticities. ${ }^{160}$

${ }^{152}$ See US - Byrd (EC) (Article 22.6) para 3.115-3.116, Annex B para 4-7, 25.

${ }^{153}$ Precise measures of confidence intervals would require knowledge of the sample variance.

${ }^{154}$ Cf. US - Byrd (EC) (Article 22.6) para 3.88-3.92, 3.115, 3.122 for a description of the US sample exclusions.

${ }^{155}$ US - Byrd (EC) (Article 22.6) para 3.87, also see Annex B para 4.

${ }^{156}$ Cf. US - Byrd (EC) (Article 22.6) para 3.96-3.103 (requesting parties), 3.105-3.119 (arbitrators), Annex B para 3-6 (arbitrators) (not providing any explanation for the model).

${ }^{157}$ Cf. US - Byrd (EC) (Article 22.6) para 3.116, Annex B para 7.

${ }^{158}$ I.e., the cross-price elasticity of demand for imports as prices of domestic products change.

159 See US - Byrd (EC) (Article 22.6) para 3.96-3.99 (requesting parties) and 3.117-3.119, Annex B para 9-10 (arbitrators). The arbitrators used the 2001-2003 average of the CDSO-weighted averages of $\eta$ and R across affected industries (cf. ibid para 3.80, 3.121, 3.123, 3.145-3.146, 3.150, Annex B para 21; for lack of more disaggregated data, values were taken at the 3-digit NAIC industry level, see ibid Annex B para 15-21) to specify a variable amount of suspension that depended only on the absolute amount of CDSO (S) in any given year (resisting the US position that the level of impairment would have to be specified as a constant in the arbitral awards, see ibid para 4.1, 4.17-4.27):

Amount of [CDSO] disbursements ... for the most recent year for which data are available relating to antidumping or countervailing duties paid on imports from the [requesting party] at that time, as published by the United States' authorities, multiplied by 0.72. (ibid para 3.151 [footnote omitted, emphasis in original], cf. Annex B para 30)

Each requesting party could count only CDSO relating to duties collected on its own imports, see ibid para 3.147$3.148,4.14-4.16$.

${ }^{160}$ Most economists would probably be satisfied with this argument to dismiss the arbitrators' 'model' (as an example of the proper economic approach, compare, e.g., the alternative model - itself not free of mistakes - of Jung \& Lee,

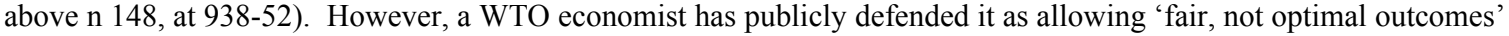
(Keck, above n 60, at 367-68). To counter this assertion, it is useful to point out a fatal shortcoming of the 'model' that can be seen using simple algebra: 
Ultimately, the shortcomings of the requesting parties' 'model' mattered little, because the arbitrators' method of allowing for different pass-through rates made the results entirely arbitrary anyway. The arbitrators introduced the pass-through rate (i.e., the proportion of CDSO that would be used for lowering prices) as an exogenous variable $\alpha$, and extended the 'model' for calculating reduction in imports to $\alpha * \eta * S * R$. This meant (and the arbitrators realized) that within the broad bounds of 0 and $\eta * S * R$, the results of the 'model' were entirely and linearly dependent on an exogenous variable $\alpha$, whose values could neither be theoretically derived nor empirically observed. ${ }^{161}$ The arbitrariness in choosing $\alpha$ is remarkable: Pushed by the arbitrators who insisted that pass-through could not be zero, the US at one point mentioned that $25 \%$ might be a reasonable number. ${ }^{162}$ The requesting parties stubbornly maintained that pass-through would be $100 \%$. So the arbitrators simply took the average of the two numbers, i.e.,

Correcting for a clear clerical error in the definition of $\eta$, the definitions of the relevant parameters were $R=\frac{P_{m} M}{P_{q} Q}$, $S=\Delta P_{q} * Q$, and $\eta=\frac{\Delta M / M}{\Delta P_{q} / P_{q}}$, where $\mathrm{M}=$ volume of imports, $\Delta \mathrm{M}=$ change in volume of imports, $\mathrm{P}_{\mathrm{m}}=$ price of imports, $\mathrm{Q}=$ volume of domestic shipments, $\mathrm{P}_{\mathrm{q}}=$ price of domestic goods, $\Delta \mathrm{P}_{\mathrm{q}}=$ change in price of domestic good. Hence, the requesting parties 'model' can be rewritten as reduction in imports =

$$
\eta * S * R=\frac{\Delta M / M}{\Delta P_{q} / P_{q}} *\left(\Delta P_{q} * Q\right) * \frac{P_{m} M}{P_{q} Q}=\Delta M * P_{m}
$$

The right hand term is the value change in imports, and indeed what the arbitrators were looking for. But it contains the unknown parameter $\Delta \mathrm{M}$. The 'model' pretends to avoid this problem by substituting the ostensibly known parameters $\eta, \mathrm{S}$, and R. Unfortunately, this simplification is an illusion. This is plain to see in the middle term, because we lack any information about the value of $\Delta \mathrm{P}_{\mathrm{q}}$, and hence by definition (!) also about $\mathrm{S}$ in the left hand term. Of course, the arbitrators and the requesting parties thought they had overcome this problem because they thought that

$S=\Delta P_{q} * Q=($ total value of CDSO disbursements)

But the critical point here is to realize that this last step is at worst a fallacy, and at best shifts the problem of an unknown variable to another term. The reason is that it confuses the initial $\mathrm{Q}\left(\mathrm{P}_{\mathrm{q}}\right)$ prevailing at price $\mathrm{P}_{\mathrm{q}}$ with the expected $\mathrm{Q}\left(\mathrm{P}_{\mathrm{q}}-\Delta \mathrm{P}_{\mathrm{q}}\right)$ resulting after the price change $\Delta \mathrm{P}_{\mathrm{q}}$. Obviously, the two are not the same - the whole calculation is based on the expectation that lowering $\mathrm{P}_{\mathrm{q}}$ will result in more domestic shipments $\mathrm{Q}$ (and less imports $\mathrm{M}$ ). Now, (2) is true only if we take $\mathrm{Q}=\mathrm{Q}\left(\mathrm{P}_{\mathrm{q}}-\Delta \mathrm{P}_{\mathrm{q}}\right)$, since the price reduction $\Delta \mathrm{P}_{\mathrm{q}}$ that needs to be financed by the CDSO disbursements will be granted on the new quantity of domestic shipments prevailing after the price reduction. But if we use $\mathrm{Q}=\mathrm{Q}\left(\mathrm{P}_{\mathrm{q}}-\Delta \mathrm{P}_{\mathrm{q}}\right)$ in (1), then in order for the equation to hold, the last component of the middle term (corresponding to R) must become $\frac{P_{m} M}{P_{q} Q}=\frac{P_{m} M}{P_{q} Q\left(P_{q}-\Delta P_{q}\right)}$. This is not the import penetration rate (neither current nor future), as claimed above, and unfortunately contains the unknown variable $\mathrm{Q}\left(\mathrm{P}_{\mathrm{q}}-\Delta \mathrm{P}_{\mathrm{q}}\right)$.

${ }^{161}$ Cf. US - Byrd (EC) (Article 22.6) para 3.113.

162 See United States, Answers to the Arbitrators' Second Set of Questions to the Parties, 7 June 2004, http://www.ustr.gov/Trade_Agreements/Monitoring_Enforcement/Dispute_Settlement/WTO/Section_Index.html (visited 8 December 2004), para 13. 
$62.5 \%{ }^{163}$ On top of being arbitrary, this number was inconsistent with the arbitrators' understanding of the underlying economics (not to speak of burden of proof!). They thought that 'the economic rationale behind a 100 per cent pass-through is strong.' 164 This seems to have been based on their understanding that

as a basic rationale of economics, firms are expected to use their money efficiently, and at least some will use that money to lower their prices. ${ }^{165}$

However, the most basic rationale of economics would seem to be that economic actors want to earn money. All other things being equal, lower prices do not serve that goal. The idea that producers might 'use those [CDSO] payments to finance price reductions ${ }^{166}$ is therefore rather odd. It is akin to suggesting that firms tend to use their profits to make presents to their customers.

\section{Level of Impairment: Some Elements of an Economic Analysis of CDSO}

To estimate the extent to which the arbitrators' end-results deviated from the true trade effects of CDSO, this subsection will briefly sketch some elements of a proper economic analysis. ${ }^{167}$ Contrary to the arbitrator's approach ${ }^{168}$, such an analysis would not focus on what producers will do with CDSO disbursements once received, because one may generally assume that producers could have financed any profitable project externally (i.e., with debt or equity) instead, and would not accept unprofitable projects in any event. ${ }^{169}$ Rather, the focus would be on what producers have to do to receive the money

\footnotetext{
${ }^{163}$ Cf. US - Byrd (EC) (Article 22.6) para 3.143-3.144, Annex B para 22-23. In fact, the arbitrators' calculations were slightly different (cf. para 146), and make one suspect that the arbitrators were uneasy with numbers; also cf. US - Byrd (EC) (Article 22.6) para 3.138, 3.146, Annex B para 29, 38.

${ }^{164}$ US - Byrd (EC) (Article 22.6), Annex B, para 9, also see para 3.141-3.142.

${ }^{165}$ US - Byrd (EC) (Article 22.6) para 3.141. The arbitrators thought that 'commercial pressures' would force a $100 \%$ 'pass-through' of CDSO (US - Byrd (EC) (Article 22.6) Annex B para 23) is incorrect in an oligopolistic or even just imperfectly competitive market.

${ }^{166}$ US - Byrd (EC) (Article 22.6) para 3.142.

167 An economically informed discussion of the effects of CDSO can be found at Congressional Budget Office, 'Economic Analysis of The Continued Dumping and Subsidy Offset Act of 2000' (with a letter from Douglas HoltzEakin, Director, to Representative Bill Thomas), 3 World Trade Review 267, at 273-76 (2004) (also available at http://www.cbo.gov/showdoc.cf.m?index=5130\&sequence=0, visited 15 December 2004).

${ }^{168}$ Cf. US - Byrd (EC) (Article 22.6) para 3.142 and Annex B para 22; also cf. United States, Written Submission, 12 March 2004, http:/www.ustr.gov/Trade_Agreements/Monitoring_Enforcement/Dispute_Settlement/WTO/Section_Index.html (visited 8 December 2004), para 67, 72-73.

169 This is of course only a first approximation. Firms' managers may not act to maximize profits, and financing difficulties may arise even for profitable projects (see generally Mark Grinblatt \& Sheridan Titman, Financial Markets and Corporate Strategy ( $2^{\text {nd }}$ edn, New York: McGraw-Hill 2002), chs 16 to 19). But if managers do not maximize profits, one would expect them to use the money to purchase more perquisites for themselves, or to extend their corporate empire through acquisition of other firms, etc., rather than to make presents (in the form of lower prices) to the firm's customers. And even if the firm had simultaneously (1) a profitable strategy of squeezing out (foreign) competitors by (temporarily) reducing prices (predatory pricing; on the conditions of profitability of such strategies generally, see Janusz A. Ordover, 'Predatory Pricing', in Paul Newman (ed), The New Palgrave Dictionary of Economics and the Law (London and New York: Macmillan Reference 1998)), and (2) financing problems that but for CDSO would prevent it from carrying out that strategy, CDSO's impact would be irreversible and presumably dramatic changes in market structure, rather than temporary and marginal effects of the type envisaged by the arbitrators.
} 
in the first place. These incentive effects of CDSO are by no means straightforward, because unlike most other subsidies, CDSO is not granted in function of current production volume or cost (which would provide direct incentives to increase production). ${ }^{170}$ 'Qualifying expenditures' may have been incurred years before the enactment of the Byrd Amendment in 2000, independently of any prospect of CDSO receipts. ${ }^{171}$ Such 'retroactive' ${ }^{172}$ reimbursements - a pure gift to companies without incentive effects - will account for the bulk of CDSO in the first years. ${ }^{173}$ Post-enactment 'qualifying expenditures' will account for a greater share of CDSO in the future ${ }^{174}$, but given the uncertainty of such future payments (in particular because the Act might be repealed), their incentive effects will be heavily discounted by producers. ${ }^{175} \mathrm{CDSO}$ may affect industry structure directly, but the effect of this on trade is rather remote and limited, and in any event its direction is not clear. ${ }^{176}$ The clearest effect of CDSO on trade could be expected to come from boosting support for petitions, because such support is required from a producer to be eligible for CDSO. ${ }^{177}$ But to count this last effect would seem to be disallowed by the Appellate Body's holding regarding the minimum domestic industry support requirement. All in all, the relevant trade effects of CDSO would seem to be close to zero. ${ }^{178}$

\footnotetext{
${ }^{170}$ In overlooking these complexities, the arbitrators are in good company, cf., e.g., Jung \& Lee, above n 148, at 939; Claire Hervey, 'The Byrd Amendment Battle: American Trade Politics at the WTO', 27 Hastings Int'l \& Comp L Rev $131,144-45$ (2003).

${ }^{171}$ For example, in the case Candle Corp of America and Blyth, Inc v US Int'l Trade Comm'n, 259 F Supp 2d 1349 (CIT 2003), qualifying expenditures had accrued since 1985.

${ }^{172}$ Cf. Congressional Budget Office, above n 167, at 274, calling CDSO 'retroactive' in this sense.

173 The rate of reimbursement will depend, of course, on the ratio of duties collected to certified 'qualifying expenditures'. In all but exceptional cases, however, this ratio will be rather small, even just looking at one fiscal year. The reason is that 'qualifying expenditures' includes most production expenses of the affected domestic producers, while duties collected are only a fraction of the value of imports. Furthermore, the rate of reimbursement is pushed downwards by the inclusion of general expenses not clearly attributable to individual products in the definition of 'qualifying expenditures', cf. 19 USC $\$ 1675 \mathrm{c}(\mathrm{b})(4)$, and US, Written Submission, above n 168, para 67, 71-72, and Answers, above n 149, para 38-39; United States, Oral Statement, 19 April 2004, http://www.ustr.gov/Trade_Agreements/Monitoring_Enforcement/Dispute_Settlement/WTO/Section_Index.html (visited 8 December 2004), para 35; Answers to the Arbitrators' Questions to the Parties, 28 April 2004, para 38-39.

${ }^{174}$ Unreimbursed 'qualifying expenditures' accumulate, see 19 USC $\$ 1675 c(d)(2)(C), \S 1675 c(d)(3)$.

${ }^{175}$ Cf. US, Written Submission, above n 168, para 13-14, 69-70.

${ }^{176}$ Exit from the industry or acquisition by a firm that did not support the original petition (which most likely includes all foreign competitors) (cf. 19 USC1675c (b)(1) in fine) disqualify a producer from CDSO. Hence, CDSO provides a strong incentive against such actions (cf. Congressional Budget Office, above n 167, at 273, regarding exit). Whether such effects were relevant in the Article 22.6 proceedings is another question, given that no finding of violation was made by the panel with respect to this condition of CDSO.

177 Cf. 19 USC $\$ 1675 \mathrm{c}(\mathrm{b})(1)(\mathrm{a})$ (requirement of support). On the incentive effect of this requirement, cf. Congressional Budget Office, above n 167, at 273, 275-76; Hale E. Sheppard, 'The Continued Dumping and Subsidy Offset Act (Byrd Amendment): A Defeat Before the WTO May Constitute an Overall Victory for US Trade', 10 Tulane Journal of International and Comparative Law 121, 129-33 (2002). This effect has already been documented in practice, cf. Kara M. Olson, 'Subsidizing Rent-Seeking: Antidumping Protection and the Byrd Amendment', working paper, 15 July 2004, http://www.ssrn.com (visited 3 August 2005); but see US, Answers, above n 149, para 33-35.

${ }^{178}$ It has even been suggested that CDSO might increase US imports, see David R. Collie \& Hylke Vandenbussche, 'Anti-Dumping Duties and the Byrd Amendment', CEPR Discussion Paper No. 4780 (December 2004), http://ssrn.com/abstract=667924 (abstract) (visited 2 August 2005).
} 


\section{F. Annex: US - Section 110(5) Copyright Act (Article 25.3)}

Although not an Article 22.6 decision, the US - Section 110(5) Copyright Act (Article 25.3) award deserves brief mention in the present discussion as the last remaining decision dealing with the level of impairment. The EC and the US had requested ad hoc arbitration under DSU Article 25 'to determine the level of nullification or impairment of benefits to the EC as a result of Section 110(5)(B) of the US Copyright Act.' ${ }^{179}$ They explicitly requested that ' $[\mathrm{t}] \mathrm{h}$ e legal principles developed in former arbitration proceedings under Article 22 of the DSU, such as the allocation of the burden of proof between the parties, shall apply to this arbitration. ${ }^{180}$

Section 110(5)(B) of the US Copyright Act as amended by the Fairness in Music Licensing Act of 1998 exempts bars, restaurants and retail establishments below certain thresholds of size and equipment from the requirement to seek authorization, and consequently to pay royalties, to copyright holders for transmitting radio and television music to their customers. ${ }^{181}$ The WTO panel requested by the EC found that this exemption was inconsistent with the US TRIPs obligation to protect copyright. ${ }^{182}$

The arbitrators decided that the relevant measure of impairment was the amount of royalty payments that EC right holders lost as a consequence of Section $110(5)(\mathrm{B}){ }^{183}$ Obviously, it did not make sense in this case to calculate impairment on the basis of trade effects in the sense of lost turnover - if anything, there would be more exploitation of EC copyrighted material in the US as a result of Section 110(5)(B). But taking royalty payments as the yardstick did make for an interesting departure from the trade effects approach, particularly once the arbitrators decided (economically sensibly) to count only royalty payments that would actually be collected by economically rational EC rights holders or their agents, net of collection cost, rather than the gross amount of royalties legally due but for Section 110(5)(B). ${ }^{184}$ In effect, the arbitrators were thus consciously

\footnotetext{
${ }^{179}$ Communication of the US and the EC to the Chairman of the DSB, WT/DS160/15, 3 August 2001. Gene M. Grossman \& Petros C. Mavroidis, 'United States - Section 110(5) of the US Copyright Act, Recourse to Arbitration under Article 25 of the DSU: Would've or Should've? Impaired Benefits Due to Copyright Infringement', 2 World Trade Review 233, 236 and 246 (2003) think the arbitrators' mandate was to set the amount of compensation, but this is too narrow, as the parties stipulated in their arbitration request that 'the award of the arbitrator shall be final, and they shall accept it as the level of nullification or impairment for purposes of any future proceedings under Article 22 of the DSU related to this dispute' (WTO/DS160/16); cf. US - Section 110(5) Copyright Act (Article 25.3) n 78.

${ }^{180}$ US/EC Communication, ibid, Annex: Agreed Procedures and Timetable for Article 25 Arbitration, $\$ 2$; cf. US Section 110(5) Copyright Act (Article 25.3) para 4.4.

${ }^{181}$ Fairness in Music Licensing Act of 27 October 1998, Pub.L. 105-298.

${ }^{182}$ More precisely, the Panel found that the exemption did not meet the requirements of TRIPS Agreement 13 and thus violated the US' obligation under TRIPS Agreement 9.1 (which incorporates Articles 11bis(1)(iii) and 11(1)(ii) of the Berne Convention into the TRIPS Agreement), WTO Panel Report, United States - Section 110(5) of the US Copyright Act (US - Section 110(5) Copyright Act), WT/DS160/R, adopted 27 July 2000, para 7.1.

${ }^{183}$ See US - Section 110(5) Copyright Act (Article 25.3) para 3.58. As suggested by the EC itself, the arbitrators (para 4.29-4.32) ignored possible effects other than direct loss of royalties that had been hinted at by the original Panel (cf. US - Section 110(5) Copyright Act, para 6.127, 6.198, 6.239-6.240).

${ }^{184}$ See US - Section 110(5) Copyright Act (Article 25.3) para 3.27-3.58. On the irrelevance of the adequacy of US enforcement provisions in this context see ibid, n 44 and Grossmann \& Mavroidis, above n 179, at 244.
} 
counting profits, i.e., economic gains. ${ }^{185}$ The prospect that the award would be used as a measure for negotiated compensation payments certainly helped frame the problem in a way to direct the arbitrators to this result. ${ }^{186}$ Not surprisingly, the award was, in absolute numbers, the second-lowest of all decisions concerned with the level of impairment (profits are always orders of magnitude lower than turnover). ${ }^{187}$ That it was also the second-lowest award relative to the original request is probably a result of the arbitrators' careful analysis of the conceptual and evidentiary problems involved. ${ }^{188}$

\section{G. Summary of Impairment Calculations}

Thus, US - Section 110(5) Copyright Act (Article 25.3) was a rather encouraging example of evaluating impairment. It was, however, not an Article 22.6 decision, and did not use trade effects. The only proper Article 22.6 decision that perhaps calculated trade effects reasonably well is EC - Hormones (US/Canada). The results were arbitrary in other Article 22.6 decisions: grossly excessive in EC - Bananas III (US) and US - Byrd, but much too low in US - 1916 Act (EC) $)^{189}$ and most likely EC - Bananas III (Ecuador). ${ }^{190}$

\footnotetext{
${ }^{185}$ Compare the arbitrators' statement that they were measuring 'economic benefits', US - Section 110(5) Copyright Act (Article 25.3) para 3.18, and the EC request to determine the 'economic value' of the denied right, ibid, para 3.3. At least in the short run, it is adequate to categorize copyright royalties as economic rents.

${ }^{186}$ Pecuniary compensation was negotiated, see below n 224.

${ }^{187}$ Compare the numbers in the table in Section V below.

${ }^{188}$ Grossman \& Mavroidis, above n 179, at 244 also find it 'difficult to find fault' with the arbitrators' calculations. The only possible exception was the arbitrators' position familiar from Article 22.6 decisions that the arbitrators 'could develop their own methodology and make their own estimates, on the basis of all arguments and evidence submitted by the parties', cf. US - Section 110(5) Copyright Act (Article 25.3) para 4.5.

In addition to the legal questions mentioned, the arbitrators needed to deal with missing data on royalty distributions from certain US collective management associations that collect royalties for rights holders, such as ASCAP and BMI, and the distribution of royalty collection (and distribution) among different sorts of rights users and uses. The arbitrators explicitly acknowledged their problem with the lack of data, see ibid para 4.15, 4.36. They excluded some data because it would have caused delay, see ibid para 4.36. Grossman \& Mavroidis, above n 179, at 245-246, argue that the arbitrators should have used their powers under DSU 13 to gather information from outside sources, even if this delayed the proceedings

The resulting complex chain of multiplications can be summarized as follows:

1996-98 average of ASCAP and BMI distributions to EC CMOs and US affiliates

*1996-1998 average share of 'general-licensing' revenues in ASCAP's domestic receipts (18.5\%, from ASCAP's annual reports)

* share of eating, drinking and retail establishments of 'general-licensing' category ( $50 \%$ guesstimate)

* share of such establishments' royalty payments attributable to radio \& TV music (confidential no., from US nat'l trade ass'ns)

* share of such establishments under thresholds of Sec. 110(5)(B) (58.5\% guesstimate based on Dun \& Bradstreet study)

* US GDP growth 1998-2001.
}

See US - Section 110(5) Copyright Act (Article 25.3) para 4.42-4.45, 4.54, 4.55-4.56, 4.57-4.59, 4.60-4.69, and 4.23 with 4.70-4.72, respectively. (ASCAP data from ASCAP; BMI distributions are calculated as (1996 BMI distributions to EC CMOs (BMI data), para 4.47) * (ratio of ASCAP distributions to EC CMOs and US affiliates to ASCAP distributions to EC CMOs only, para 4.49) * (growth rate of ASCAP distributions 1996-1998, para 4.50).)

${ }^{189}$ This is not too say that permissible retaliation in US - 1916 should have been high in absolute amounts - but it was too low relative to what it should have been. 


\section{IV.The Special Case of Prohibited Subsidies AND Appropriate} COUNTERMEASURES UNDER SCM ARTICLE 4.11

The picture that emerges from Sections I to III does not get better when looking at the special Article 22.6 proceedings dealing with prohibited export subsidies under SCM Article 4.11. As is well known, 'rebalancing' or equating the levels of impairment and suspension was not even attempted in the three cases to date. In the eyes of the different arbitrators charged with determining 'appropriate countermeasures' (SCM Article 4.10), various benchmarks could be used, such as lost profits, lost trade, or the amount of the subsidy. Neither of them constituted an upper bound, and the arbitrators seem to have accepted whatever criteria the complaining Member put forward as long as that criteria had been correctly measured. ${ }^{191}$ In the end, the level of 'appropriate countermeasures' was set at the total amount of the subsidy in all awards. ${ }^{192}$ The result were the WTO's highest suspension awards, with authorization for suspension in the amounts of CAN\$344.2 m (Brazil - Aircraft), US\$247.8 m (Canada - Aircraft II), and US\$4,043 m (US - FSC), respectively.

In justification of this 'trigger-friendly' approach, the arbitrators pointed primarily to the lack of any mention of trade effects or impairment in SCM Articles 3 and 4, in contrast to other articles of that Agreement. ${ }^{193}$ They also emphasized that the export subsidies at issue were prohibited subsidies that, unlike other WTO-inconsistent measures, had to be withdrawn 'without delay' under SCM Article 4.7. ${ }^{194}$ But whatever one may think of these considerations, it is hard to see why they would relieve the interpreter of finding a principled meaning of 'appropriate'. ${ }^{195}$ A convincing interpretation of SCM Articles 4.10 and 4.11 and their infamous footnote 9/10 cannot rely on the impenetrable wording and would require the formulation of an underlying (economic) theory for the special treatment of countermeasures against prohibited

\footnotetext{
${ }^{190}$ Perhaps there are some theories of 'rebalancing' retaliation which do not depend on exact impairment calculations, as long as the errors remain within certain bounds and/or cancel out on average (see, e.g., Kohler, above $\mathrm{n} 3$ ). It is too early to tell whether the errors will cancel out on average, or whether there is a systematic bias in the impairment calculations (in any event, there is for the time being a systematic bias in the definition of suspension, see above Section II.A). But certainly the errors have so far have been very large.

${ }^{191}$ Cf. Brazil - Aircraft (Article 22.6) para 3.19, 3.21, 3.27, 3.60, 3.62 (Canada requested, and the arbitrators 'selected the amount of the subsidy as the basis for the countermeasures'); US - FSC (Article 22.6) para 5.24 (text neither precludes injury-based calculation nor confines countermeasures to such a test); Canada - Aircraft Credits and Guarantees (Article 22.6) para 3.13 (no methodology excluded a priori), 3.20-3.26 (rejecting trade effects because it yields zero in the present case).

${ }^{192}$ See Brazil - Aircraft (Article 22.6) para 3.60, 3.66; US - FSC (Article 22.6) para 6.10-32; Canada - Aircraft Credits and Guarantees (Article 22.6) para. 3.60.

${ }^{193}$ Cf. Brazil - Aircraft (Article 22.6) para 3.46-3.49; US - FSC (Article 22.6) para 5.23, 5.32-5.37; Canada - Aircraft Credits and Guarantees (Article 22.6) para 3.10, 3.13.

${ }^{194}$ Cf. Brazil - Aircraft (Article 22.6) para. 3.45; US - FSC (Article 22.6) para. 5.37-5.40, 6.22 ('countering the legal breach as a wrongful act'); Canada - Aircraft Credits and Guarantees (Article 22.6) para 3.9, 3.11, 3.13.

${ }^{195}$ For a legal critique of the arbitrators' approach, see Palmeter \& Alexandrov, above n 3, at 652-59, and for US - FSC (Article 22.6) in particular see the damning comment of Robert Howse \& Damien J. Neven, 4 World Trade Review 101 (2005).
} 
subsidies. Such a theory would then permit the principled interpretation of 'appropriate' in light of its purpose, as required by VC Article 31. ${ }^{196}$ The only defense of the arbitrators is that, surprisingly given the high awards, none of the responding Members ever objected to measuring impairment by the amount of the subsidy. ${ }^{197}$

With the current regime, it is hard to see what exactly it achieves, except generating huge suspension awards. ${ }^{198}$ Clearly there is only aesthetic interest in assuring that some subsidy and some amount of trade can be expressed in the same number. ${ }^{199}$ There is a little more intuitive appeal to the idea that the retaliatory tariffs should 'skim off' the entire amount of the subsidy. ${ }^{200}$ But if that were the goal, countermeasures themselves would have to be measured in terms of tariff revenue, not trade. ${ }^{201}$ And it is almost inconceivable that the retaliating Member will ever have all at once the ability, the economic incentive, and the need to use 'appropriate countermeasures' to 'skim off' the subsidy. ${ }^{202}$ Furthermore, the huge awards are not even a guarantee that suspension will be allowed at least at the level of impairment nor, for that matter, at a level sufficient to deter the subsidy. ${ }^{203}$ As the arbitrators themselves recognized, the level of impairment generated by a subsidy can be much higher than the subsidy itself (as in the case of strategic trade subsidies - Aircraft cases) - but it can also be much lower (and even negative in the case of an unfocused subsidy that operates, from the recipient country's view, like a gift). ${ }^{204}$

Given the lack of principle in choosing the relevant criteria by which to measure 'appropriate', one wonders why the arbitrators then spent so much time finding the right value for that criteria, once chosen. Canada - Aircraft Credits and Guarantees (Article 22.6) is paradigmatic. ${ }^{205}$ After a detailed calculation of the value of the subsidy, the arbitrators decided to add an arbitrary $20 \%$ to that amount to determine the permissible level of suspension. ${ }^{206}$

\footnotetext{
${ }^{196}$ On possible purposes of retaliation see above Section I and below Section VI.

${ }^{197}$ See Brazil - Aircraft (Article 22.6) para 3.23-3.26 (Brazil); US - FSC (Article 22.6) para 3.1 (US); Canada Aircraft Credits and Guarantees (Article 22.6) para 3.2 and 3.16 (Canada).

${ }^{198}$ Compare Lawrence, above $\mathrm{n}$ 3, at 59.

${ }^{199}$ Cf. US - FSC (Article 22.6) para 6.19, describing the retaliatory tariffs on this amount of trade as 'a congruent duty' and a 'mirror withdrawal of an obligation' corresponding to the illegal expense. But what kind of mirror reflects a subsidy payment of value $\mathrm{X}$ as a retaliatory tariff of size $\mathrm{Y}$ on goods of value $\mathrm{X}$ ?

${ }^{200}$ Cf. US - FSC (Article 22.6) para 6.21.

${ }^{201}$ US - FSC (Article 22.6) para 8.1 explicitly specified the countermeasure as a $100 \%$ ad valorem tariff on trade valued at the amount of the subsidy.

202 The ability would generally assume that the export subsidy is granted on goods destined for the retaliating Member. But in this case, countervailing measures under the SCM would be sufficient. So the interesting case is where the subsidizing Member's and the retaliating Member's industries compete on a third market, in which case 'skimming off' will be a hard thing to do.

${ }^{203}$ This seems to be not understood by US - FSC (Article 22.6) para 6.56.

${ }^{204}$ Cf. Brazil - Aircraft (Article 22.6) para 3.54; US - FSC (Article 22.6) para. 6.39-6.41.

${ }^{205} \mathrm{Cf}$. Lawrence, above n 3, at 58 .

${ }^{206}$ See Canada - Aircraft Credits and Guarantees (Article 22.6) para 3.119-3.122.
} 


\section{SPLitTing THE Difference?}

Given the many shortcomings in the official arguments of the arbitrators and the high level of arbitrariness at decisive junctures, one may wonder whether the lengthy reports were just a legalistic cover for what were ultimately diplomatic solutions to the underlying conflicts. ${ }^{207}$ Perhaps the diplomatic explanation of EC - Bananas III (US) (Article 22.6) given above can be generalized at a very simple level: arbitrators usually split the difference. ${ }^{208}$ The following table provides an overview of complaining parties' demands ('ask'), responding parties' 'offers', their arithmetic average, and the actual awards in all cases (all amounts in US\$ unless otherwise noted).

\begin{tabular}{|l|l|l|l|l|}
\hline Case & Applicant's 'ask' & Respondent's 'offer' & (Ask + offer)/2 & Award \\
\hline EC - Bananas III (US) & $520 \mathrm{~m}$ & 0 & $260 \mathrm{~m}$ & $191.4 \mathrm{~m}$ \\
\hline EC - Bananas III (ECU) & $450 \mathrm{~m}$ & $?$ (assumption: 0) & $225 \mathrm{~m}$ & $201.6 \mathrm{~m}$ \\
\hline EC- Hormones (US) & $202 \mathrm{~m}$ & $53.3 \mathrm{~m}$ & $127.7 \mathrm{~m}$ & $116.8 \mathrm{~m}$ \\
\hline EC - Hormones (CAN) & $75 \mathrm{~m} \mathrm{C \$}$ & $3.5 \mathrm{~m} \mathrm{C \$}$ & $39.3 \mathrm{~m} \mathrm{C \$}$ & $11.3 \mathrm{~m} \mathrm{C \$}$ \\
\hline US - 1916 (EC) & (mirror legislation) & 0 & NA & 0 \\
\hline US - Byrd & CDSO+ ${ }^{209}$ & 0 & $.5 \times \mathrm{CDSO}+$ & $.72 \times \mathrm{CDSO}$ \\
\hline Brazil - Aircraft & $700 \mathrm{~m} \mathrm{C \$}$ & $($ confidential; & $350 \mathrm{~m} \mathrm{C \$}$ & $344.2 \mathrm{~m}$ C\$ \\
\hline US - FSC & & $1,110 \mathrm{~m}$ & $2,576.5 \mathrm{~m}$ & $4,043 \mathrm{~m}$ \\
\hline Canada - Aircraft II & $3,360 \mathrm{~m}$ & 0 & $1,680 \mathrm{~m}$ & $247.8 \mathrm{~m}$ \\
\hline US - Sec 110(5) Copyright & $25.5 \mathrm{~m}$ & $.7 \mathrm{~m}$ & $13.1 \mathrm{~m}$ & $1.2 \mathrm{~m} €$ \\
\hline
\end{tabular}

${ }^{207}$ Cf. Hudec, above n 3, at 23-25 (noting that retaliation awards under the GATT 1947 and the EC - Bananas III (Article 22.6) decisions concealed their precise calculations, and that 'the important thing is not the fact of equivalence itself, but rather having some credible mechanism which can certify equivalence in a politically persuasive way.' (at 23)).

${ }^{208}$ This idea has first been advanced by Bernstein \& Skully, above n 3, at 389-90, 394-96 under the impression of EC Hormones (US/Canada) (Article 22.6); also see Marc L. Busch \& Eric Reinhardt, 'Testing International Trade Law: Empirical Studies of GATT/WTO Dispute Settlement', in Kennedy \& Southwick, above n 3, 457, at 478.

209 The requesting parties claimed impairment in the amount of CDSO corresponding to duties on their own imports plus a pro-rata share of CDSO corresponding to duties on imports from countries that did not complain to the WTO, see US - Byrd (EC) (Article 22.6) para 1.5, and the arbitrators' rejection para 3.147-8. Canada also requested suspension of certain obligations under SCM and the Anti-Dumping Agreement, see Decision by the Arbitrators, United States Continued Dumping and Subsidy Offset Act of 2000 - Original Complaint by Canada - Recourse to Arbitration by the United States under Article 22.6 of the DSU, WT/DS234/ARB/CAN, 31 August 2004, para 1.7. CDSO distributions are expected to total about US\$300 m per year, see Congressional Budget Office, above n 167, at 272.

However, it should also be noted that the arbitrators in US - Byrd rejected the complaining parties' request of a much more aggressive method of specifying suspension, see discussion above $\mathrm{n} 26$. 
The average of 'ask' and 'offer' is close to the actual award in EC - Bananas III, EC Hormones (US), US - Byrd and Brazil - Aircraft. Perhaps EC - Hormones (Canada) and Canada - Aircraft II can best be explained by a desire to stay in proportion with their sister decisions EC - Hormones (US) and Brazil - Aircraft, respectively (notice the similar amounts in the aircraft cases, and the proportions of Canada/US shares of the world beef market in the Hormones case). ${ }^{210}$ A case-specific political economy explanation of US - 1916 Act was already suggested above. Thus, the only cases that do not fit in the pattern are US - FSC and US - Section 110(5) Copyright Act, and the latter is not a retaliation case.

\section{PROPOSALS FOR IMPROVEMENT}

In any event, splitting the difference is hardly a satisfactory explanation for decisions that may harm and potentially wipe out billions of trade annually, not to speak of the fate of individual businesses. ${ }^{211}$ But while it is easy to criticize the current system, solid recommendations for improvement are much harder to come by, and in any event the most important of them would have to be implemented by treaty amendments rather than arbitrators' decisions.

Barring treaty amendments, arbitrators will obviously have to discharge their mandate under the current DSU Article 22.4 even though an equivalent level of suspension may be neither sensible nor achievable. Proposed changes such as compulsory monetary compensation $^{212}$ or contingent liberalization requirements ${ }^{213}$ would have to be agreed upon between the Members. For the time being, arbitrators will in particular continue to face the dilemma of choosing between two similarly unsatisfactory comparators for implementing DSU Article 22.4 (trade effects or economic gains/losses). If trade effects remain the arbitrators' choice, a more context-specific operationalization may allow more meaningful comparisons of impairment and proposed suspension. For the same purpose, a new balance between DSU Article 22.4 and the first sentence of DSU Article 22.7 may have to be found.

But whatever their ultimate choices regarding these general lines, arbitrators owe it to the reputation of the WTO dispute settlement system to support these choices with conscious and well-reasoned explanations under the treaty text, even if this means

\footnotetext{
${ }^{210}$ Cf. Canada - Aircraft Credits and Guarantees (Article 22.6) para 3.40-3.41 (explicitly taking this relationship into consideration).

${ }^{211}$ Cf. O'Connor, above n 77, at 263: 'Law is not about guesses especially in the field of sanctions.' Some authors discuss the possibility that the precise level of authorized retaliation does not matter. Araki, above n 3, at 349, points out that precise measurements are also lacking at the negotiation table, but presumably would agree that at least the rough measures used in negotiations would have to be respected. Kohler, above n 3, at 334, argues that, based on a reciprocal terms-of-trade model with political economy preferences, efficiency does not require precise measurements, but nevertheless insists that retaliation lie within a certain range of values. On Hudec, above n 3, at 23-25, see below n 223.

${ }^{212}$ Cf. Marco Bronckers \& Naboth van den Broek, 'Financial Compensation in the WTO: Improving the Remedies of WTO Dispute Settlement', 8 JIEL 101 (2005) (advocating monetary compensation).

213 Cf. Lawrence, above n 3, chapter 5 (advocating lists of 'alternative' commitments by Members, to be activated instead of others they may be violating).
} 
acknowledging the latter's weaknesses. Similarly, once chosen, they must apply these general lines consistently and with the greatest possible care. No system of adjudication can allow itself too many decisions as weak as the Article 22.6 decisions in US - 1916 Act and US - Byrd. If necessary, arbitrators should exceed the 60 days timeframe of DSU Article 22.6 rather than render an unconvincing award. ${ }^{214}$ The DSB, the WTO Secretariat and its Director-General may be able to give some help by proposing and appointing more arbitrators with expertise in economics, although this will be difficult as it seems that this would have to be done already at the Panel stage. ${ }^{215}$ In the long run, DSU reform might bring in a parallel panel of economic experts, a kind of economists' jury, to rule on the economic issues of the case within the legal framework set by the arbitrators. Certainly appeals from Article 22.6 decisions to the Appellate Body should be allowed to ensure more consistency. ${ }^{216}$

Arbitrators could avoid many errors simply by more strictly adhering to the burden of proof - it is so much easier to take a back seat and criticize what the parties are putting forward than to try to come up with one's own estimate, as past Article 22.6 decisions did. Stricter adherence to the burden of proof would, however, raise the stakes involved in its initial allocation. As Section III.A. pointed out, legal arguments based only on general principles of law and the structure of Article 22.6 proceedings are inconclusive in this respect. Whether the burden of proof should remain on the responding Member, as in current case-law, or be moved to the complaining Member, would thus seem to depend on the object and purpose of the relevant DSU provisions and the retaliation mechanism they support, and in particular on whether retaliation awards should err on the high or low side of the optimal level. Once again, our present understanding of compliance and enforcement is hardly sufficient to provide a clear answer. ${ }^{217}$ On the one hand, retaliation should not be allowed to fall below certain thresholds if direct trade retaliation, or rather the threat of such retaliation, were what keeps the world trading system together (in some form of tit-for-tat mechanism). ${ }^{218}$ On the other hand, even if the threat of direct trade retaliation were key to enforcement, excessive retaliation might be counterproductive because it exacerbates the cost of retaliation where compliance is not forthcoming, leads

\footnotetext{
${ }^{214}$ Cf. EC - Bananas III (US) (Article 22.6) para 2.12; and the critique of Grossmann \& Mavroidis, above n 188, concerning US - Section 110(5) Copyright Act (Article 25.3).

${ }^{215}$ DSU Article 22.6 seems to mandate the appointment of the original panel, if its members are available, for Article 22.6 proceedings.

${ }^{216}$ The DSU does not provide for the possibility of an appeal of Article 22.6 decisions. This is particularly troublesome because Article 22.6 proceedings have also been completely lacking personal continuity. No arbitrator has worked on more than one standard Article 22.6 case (counting multiple complaints regarding the same measure as one case); only one arbitrator, Seung Wha Chang, has worked on two export subsidy cases (US - FSC (Article 22.6) and Canada Aircraft Credits and Guarantees (Article 22.6)) .

${ }^{217}$ Cf. Kal Raustiala \& Anne-Marie Slaughter, 'International Law, International Relations, and Compliance', in Walter Carlsnaes, Thomas Risse \& Beth A. Simmons (eds), Handbook of International Relations (London; Thousand Oaks, CA: Sage Publications 2002), 538 (discussing the various theories and empirical studies on compliance with international law pointing in different directions).

${ }^{218}$ See, e.g., Lawrence, above n 3, at 64; cf. Juergensen, above n 3, who fears that the effectiveness of trade sanctions is jeopardized by watering down the permissible level of retaliation, even though he recognizes the importance of reputational sanctions and acknowledges that the impact of sanctions has been limited in the past.
} 
to compliance even where the cost of compliance outweigh its benefits, and ultimately reduces the possible benefits from bargaining available ex ante. ${ }^{219}$ In addition, it is by no means certain that direct retaliation plays a major role in enforcing international law reputation concerns in the infinitely repeated game of international interaction might be much more important. ${ }^{220}$ In international trade law in particular, the importance of direct trade retaliation is put into doubt by the success of the GATT, the significant limitations on retaliation in the WTO, and observed behavior of state actors. ${ }^{221}$

But if the broader costs and benefits of retaliation, and of certain levels of retaliation, are hard to ascertain, perhaps there is an argument to be made to be guided by the immediate effect of retaliation, which is obviously a trade distortion causing a net welfare reduction. In this limited perspective, welfare concerns and the WTO's commitment to free trade argue for keeping this immediate effect, and thus retaliation, as low as possible. ${ }^{222}$ Any ancillary benefits of retaliation, such as a publicity effect and a valve for letting out domestic interest group pressure, would still be respected by more modest retaliation. ${ }^{223}$ Lower retaliation awards would also make it cheaper for the responding Member, and thus overall easier, to resolve the dispute by compensation (in cash or additional trade commitments) as a trade-friendly voluntary alternative to suspension. In this connection, it is worth remembering that the best decision regarding the level of impairment, US - Section 110(5) Copyright Act (Article 25.3), yielded the second-lowest award both in absolute numbers and relative to the original request using a measure of

\footnotetext{
219 See, e.g., the references above n 40; and on the dangers of excessive legal limits in international trade relations generally Judith Goldstein \& Lisa L. Martin, 'Legalization, Trade Liberalization, and Domestic Politics: A Cautionary Note', 54 International Organization 603 (2000).

${ }^{220}$ For an exposition of the idea of international law supported by reputation see, e.g., Andrew T. Guzman, 'A Compliance-Based Theory of International Law', 90 California Law Review 1823 (2002).

${ }^{221}$ On the enforcement of GATT without a formal sanction mechanism (while in principle foreseen under GATT Article XXIII, sanctions required approval of the violating Member (!) itself under the positive consensus rule), see Robert E. Hudec, Enforcing International Trade Law: The Evolution of the Modern GATT Legal System (Salem, N.H.: Butterworth, 1993). On the limitations of retaliation under the WTO, in particular the forced time-lag and the prohibition of retroactive and/or punitive remedies, see, e.g., Shannon K. Mitchell, 'GATT, Dispute Settlement, and Cooperation: A Note', 9 Economics and Politics 87 (1997). For an example of an at least superficially unexpected compliance pattern, consider the fate of the US 1916 Act and the Byrd Amendment, respectively: the US repealed the former even though US - 1916 Act (EC) (Article 22.6) effectively denied the EC the right to retaliate, while the opposite occurred in US - Byrd (massive sanction award, no repeal as of this writing), see above n 117 and 139 and following text.

${ }^{222}$ Cf. Charnovitz, above n 3, at 809-12, 815-16 (mustering arguments against sanctions, based in particular on the WTO's goals and public message).
}

Matters are somewhat complicated by the observation that lower retaliation awards may sometimes lead to higher retaliation. This is the case where the complaining Member suffers a welfare loss from implementing retaliation (especially small countries without the possibility to use optimal tariffs), but derives a reputation benefit from exercising all authorized retaliation. The lower the award, the higher the likelihood that the latter benefit will prevail and retaliation will be implemented. But in this case, the overall welfare loss from retaliation in the individual case is perhaps compensated by the increase in the overall credibility of the dispute settlement system.

${ }^{223}$ Compare Hudec, above n 3, at 22-25, who points out that it is not equivalence as such, but political persuasion of equivalence through a credible process that matters. 
economic profits, apparently without upsetting the complaining Member (EC), and resulted in negotiated cash compensation (at least as a temporary solution). ${ }^{224}$

Hence, arbitrators should put the burden of proof on the complaining Member, and err on the low side of retaliation awards. 'Rebalancing' retaliation has been revealed to be a myth anyway.

224 On the calculations and the approach of the decision, cf. above Section III.F; and on the settlement see Communication from the US and the EC to the Chairman of the DSB, WT/DS160/23, 26 June 2003. But see Bernard O'Connor \& Margareta Djordjevic, 'Practical Aspects of Compensation - The US - Copyright Case', 7(4) JIEL (forthcoming 2005), arguing that monetary compensation only to the EC violated the most-favored nation principle, and drawing attention to the (EC-internal) practical and legal problems involved in distributing the money to stakeholders in the EC. 